The Impact of Family Setting and Local Opportunities on Leaving Home and Migration Destinations of Rural Youths, The Netherlands 1860-1940

Bastian Mönkediek, Jan Kok \& Kees Mandemakers

Historical Life Course Studies, Volume 3, 43-65.

Published 2016-11-02

Citation

Mönkediek, B., Kok, J. \& Mandemakers, K. (02-11-2015). The Impact of Family Setting and Local Opportunities on Leaving Home and Migration Destinations of Rural Youths, The Netherlands 1860-1940. Historical Life Course Studies, Volume 3, 43-65. http://hdl.handle.net/10622/23526343-2015-0005?locatt=view:master

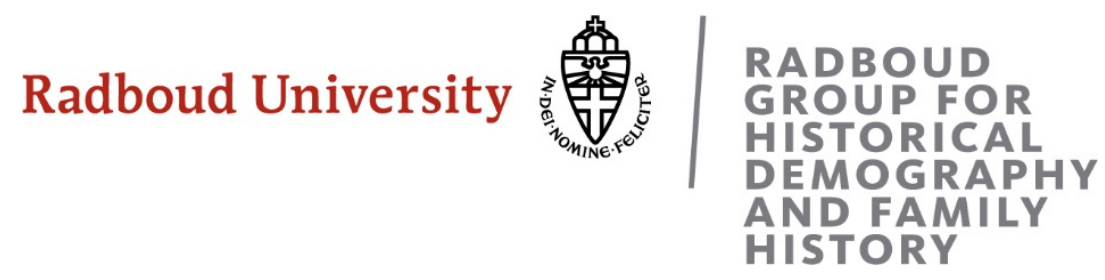




\section{HISTORICAL LIFE COURSE STUDIES}

\section{VOLUME 3}

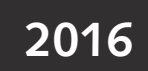




\section{HISTORICAL LIFE COURSE STUDIES}

Historical Life Course Studiesis the electronicjournal of the European Historical Population Samples Network(EHPS-Net). The journal is the primary publishing outlet for research involved in the conversion of existing European and non-European large historical demographic databases into a common format, the Intermediate Data Structure, and for studies based on these databases. The journal publishes both methodological and substantive research articles.

\section{Methodological Articles}

This section includes methodological articles that describe all forms of data handling involving large historical databases, including extensive descriptions of new or existing databases, syntax, algorithms and extraction programs. Authors are encouraged to share their syntaxes, applications and other forms of software presented in their article, if pertinent, on the EHPS-Net website.

Research articles

This section includes substantive articles reporting the results of comparative longitudinal studies that are demographic and historical in nature, and that are based on micro-data from large historical databases.

Historical Life Course Studies is a no-fee double-blind, peer-reviewed open-access journal supported by the European Science Foundation (ESF, http://www.esf.org), the Scientific Research Network of Historical Demography (FWO Flanders, http://www.historicaldemography.be) and the International Institute ofSocial History Amsterdam(IISH, http://socialhistory. org/). Manuscripts are reviewed by the editors, members of the editorial and scientific boards, and by external reviewers. All journal content is freely available on the internet at http://www.ehps-net.eu/journal.

Editors: Koen Matthijs \& Paul Puschmann

Family and Population Studies

KU Leuven, Belgium

hislives@kuleuven.be

The European Science Foundation (ESF) provides a platform for its Member Organisations to advance science and explore new directions for research at the European level. Established in 1974 as an independent non-governmental organisation, the ESF currently serves 78 Member Organisations across 30 countries. EHPS-Net is an ESF Research Networking Programme.

The European Historical Population Samples Network (EHPS-net) brings together scholars to create a common format for databases containing non-aggregated information on persons, families and households. The aim is to form an integrated and joint interface between many European and non-European databases to stimulate comparative research on the micro-level.

Visit: http://www.ehps-net.eu.
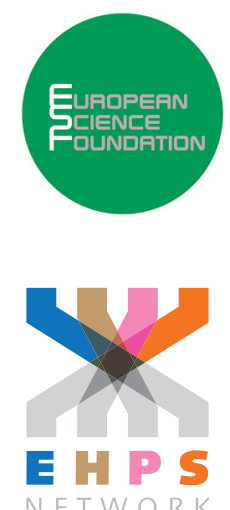


\title{
The Impact of Family Setting and Local Opportunities on Leaving Home and Migration Destinations of Rural Youths, The Netherlands 1860-1940
}

\author{
Bastian Mönkediek \\ Wageningen University
}

Jan Kok

Radboud University Nijmegen

Kees Mandemakers

International Institute of Social History

\begin{abstract}
In this article we aim to study how Dutch children's individual destinies result from the complex interplay of family setting and local conditions in a rural environment. We focus on their final move from the parental home, and we will analyse not only timing and incidence of leaving, but also the destinations. To do this, we propose a multi-level competing risk analysis of migration destinations. We focus on two groups: the children of farmers and those of rural workers. Dutch farmers and workers differ in the type of family economy in which children were integrated, and contrasting them will allow us to explain the speed, the directions, and the individual and family backgrounds of the process of leaving agriculture. We make use of the Historical Sample of the Netherlands to analyse last migrations of 8,338 children of farmers and rural workers. As we cover the entire country, we can study the full impact of regional differences on type of agriculture and inheritance, in combination with the family composition. Our results indicate significant effects of specialised versus traditional, mixed farming on the migration behaviour of farmers' and rural workers' children, as well as the importance of the number of siblings of the same sex and birth order. The variations in the effects of the sibship among regions with different agricultural systems demonstrate the importance of gender-specific divisions of labour on leaving home.
\end{abstract}

Keywords: Sibship, Leaving home, Competing risk analysis, Migration, Youths, Rural, Netherlands

e-ISSN: $\quad$ 2352-6343

PID article: $\quad$ http://hdl.handle.net/10622/23526343-2015-0005?locatt=view:master

The article can be downloaded from here.

(C) 2015, Bastian Mönkediek, Jan Kok, Kees Mandemakers.

This open-access work is licensed under a Creative Commons Attribution 4.0 International License, which permits use, reproduction \& distribution in any medium for non-commercial purposes, provided the original author(s) and source are given credit. See http://creativecommons.org/licenses/ 
The decline of farming, and especially the virtual disappearance of crofting, has had strong implications for rural society of the Netherlands in the twentieth century. Traditional social relations - social control mechanisms as well as systems of mutual support - have eroded. The economic and demographic viability of village life has been put under pressure. In many areas land use and ecology have changed drastically (Bieleman 2008). In the late nineteenth century, several regions already witnessed an outflow of superfluous workers' and farmers' children, for instance in order to find work in the expanding cities or to emigrate. This outflow was an uneven process where 'push' factors (such as the Agrarian Depression) and 'pull' factors (such as urban employment) differed in strength across periods and regions (e.g. Swierenga \& Saueressig-Schreuder 1983; Wintle 1992). Furthermore, contextual and family factors played a role in the outflow process, but the mechanisms are not completely understood. At the same time, the insights we gain from studying the process of rural outflow in the Netherlands in the past are useful to understand the ongoing drift away from rural regions in today's developing countries (Abramitzky, Boustan \& Eriksson 2013). Accordingly, in this article, we take a new look at the process of rural out-migration to better understand to what degree contextual and family factors framed the migration behaviour of the Dutch rural society. In doing so, we focus on Dutch children's migration destinations. We compare the final moves away from home of the children of agricultural workers and farmers from ages 12 to 30 and aim to answer the questions: Under what circumstances did children tend to stay at home or in the area? And in what circumstances did they go to another region, to a city, or even abroad? Were there differences in the migration destinations of farmers' and agricultural workers' children? We are interested in the interplay of contextual and family factors, and we propose a technique that makes it possible to contrast their effects on the full array of migration decisions. We focus on fina/moves from home, in contrast to previous work concentrating on first moves (Kok 1997; Bras \& Kok 2004), because we expect the final move to be a better indicator of individual decision-making regarding staying or leaving one's native rural area.

\section{THEORETICAL BACKGROUND}

Differences in the process of leaving home for children of workers and farmers have to be understood, first and foremost, from the different family economies in which they belonged. In the Netherlands, children of landless workers could not contribute much to the family income by staying at home (Dribe 2004). Boys might have joined their father on the farm where he worked and also helped him on his plot of rented land, but for girls going into domestic service was often the only option. Generally, in the nineteenth century girls from rural workers' families left home earlier than boys, especially when there were younger sisters who could help the mother. However, girls could stay longer when they had older brothers who could add to the family income (Bras \& Kok 2004). Children working in service often returned home between employments (Kok 1997). We can assume that, at least until the final move from home, they remained integrated in the family economy, as the parents mostly decided who should go into service (Bras \& Kok 2004)

Until about 1900, Dutch children, regardless of whether they worked from home or lived elsewhere, were often expected to hand over their income to the parents (Bras \& Kok 2004). Traditionally, this was most obvious in the Dutch regions of North Brabant and Limburg where children often worked for their parents without pay and handed over their earnings when they were sent out to work as farmhands or maids (Klep 2011). In these regions, children were often closely bound to their parent's household; they stayed home for a long time and married at later ages. They often followed their parent's expectations in anticipation of inheriting family property, such as a plot of land (Klep 2011). In the Dutch coastal regions, including Groningen, Friesland, North and South Holland, Utrecht and Zeeland, parental control on children was looser. In these regions, children often were sent away to work as servants or farmhands and only paid board money to their parents when they stayed at their parent's home. Children left home and married much earlier than in the regions of North Brabant or Limburg, because their chances to stay in the area were small, since farm size was often limited and buying land was expensive (Klep 2011). Similar patterns of early migration and early marriage were observed in several eastern and south-eastern Dutch regions, including Drenthe, Overijssel and Gelderland. Again, children had to pay board wages when they stayed in their parent's households; in some cases they also handed over their earnings to support their parents. This behaviour was facilitated by rules of partible inheritance which made it attractive for only one child to stay in the parent's vicinity (Klep 
2011). Accordingly, in the first half of the nineteenth century the fulfilment of parents' expectations to receive income from their children or be supported at older ages varied a lot between Dutch regions. In addition, older children and especially those living farther away from their parents often managed to keep part of their salaries for themselves, and could begin to save for their marriages (Kok 1997).

Farmers' children participated in the family economy from early ages, and their contribution was integral to the working of the farm. Their experience and skills, as well as the option to inherit at least a share of the family property, created specific incentives to invest in a farming career. We assume that for many farmers' children the feasibility to continue farming was a major factor in life planning. The feasibility, of course, is determined by many factors. It depended on the economic success of the family in question, the size of the family, the size of the farm, the age of the parents and the possibility to obtain an advance on the inheritance, as well as inheritance rules (Dribe 2000; Florey \& Guest 1988). It also depended on the economic prospects for agriculture in a particular region, since the Netherlands is characterised by a broad mixture of agricultural types which differ in the labour intensity and in the prospects they offer children to stay in the agricultural business (Knippenberg \& de Pater 1988; Verslag van den Landbouw 1875).

The coastal areas of the west are characterised by a soil type called 'Geestgronden' which offered favourable conditions for commercialised floriculture. This sector expanded rapidly after 1880 by removing dunes and the sandy top-soils. Bulb-growing was lucrative, yet very labour intensive, and the farmers often relied on their children's labour (Kok, Mandemakers \& Damsma 2010). In the commercialised farming regions live-in servants were replaced with day labourers, a process which occurred in many parts of Europe (Sarti 2007). Commercial, specialised farms did not offer year-round employment for servants and preferred day-labourers. This also meant that the social distance between farmers and workers increased. Thus, the presence of children was even more valued in those families for helping out their parents, but working for other farmers began to be considered demeaning. The traditional three-field system of mixed agriculture still prevailed in those parts of eastern and southern Netherlands which were covered by sandy soil. After about 1850, farmers in these regions focused more on production for the market (e.g. pigs and poultry), reclaimed land and increased productivity. In between, often along the rivers and near the sea, grain cultivation on clay soil dominated, which as we have discussed above, suffered after 1880 due to cheap grain imports from the U.S. and other regions profiting from railways and steamships (Kok 2003; Paping 2004).

In the context of these agricultural types, parents may make tactical decisions regarding who to send away and who to keep, taking their own old age care into consideration (e.g. Jensen \& Miller 2011). In practice, middle-rank children migrated most often, both in America and Europe (Adams \& Kasakoff 1992; Bonneuil, Bringé \& Rosental 2007). However, other family pressures played a role too. The likelihood to leave also depended on the size and sex composition of the family. The literature shows that across agricultural types, farmers expected from and invested in their sons and daughters differently, leading to gender-specific prospects of remaining in agriculture, and siblings of the same sex creating pressure to leave home (Dribe 2000). A study of the life courses of American farmers' sons around 1900 showed that younger sons more often stayed at home if the household mainly consisted of women (Abramitzky et al. 2012; Florey \& Guest 1988). In the Netherlands, in the commercial cereal farming regions, e.g. in northern Groningen, women had, at most, supervisory tasks and hardly participated in the actual (physical) work. Increasingly, daughters were sent to (urban) boarding schools to refine their manners (Saal 1958). Sons, however, did not receive secondary education, as this was not deemed necessary for farming. In 1917, an observer wrote: "In giving a more urban-style education to the girls than to the sons, there was the risk that the girls raised as 'ladies', on returning to their parents, did not feel at home any more. Often, they preferred to marry a doctor, church minister or lawyer, than to remain in the countryside in an environment, where the men had received a lower education than themselves" (Minderhoud 1917, cited in Berg 1989: 41). A very different situation is found in the dairy farming regions. The making of butter and cheese was women's work, handed down from mother to daughter. Although the work was tedious and very time-consuming, women were very proud of the quality products that they made. They also gained, to some extent, some independence, as they often marketed or bartered the products themselves. After deducting household expenditures, they would still hand over the profits to their husbands, but this still gave them more bargaining power in the household than other (farmers') wives. Therefore, in many regions farmer women resisted the shift toward industrial dairy production which heralded the end of a typical female occupation (Lodder 1989; Shortall 2000; Verstoep 1989). Floriculture did require women's labour (bulbs peeling), but only during the summer months. Overall, it required intense labour input by men (Arnoldus 2003). Nevertheless, the income generated in the most commercialised areas (floriculture, dairy and grain) may have allowed farmers' children to leave home earlier (e.g. for marriage or starting a business somewhere else), and we hypothesize that when they left, they would be less inclined to choose local and regional 
migrations (indicating live-in service) than children in the regions with mixed agriculture. On the self-sufficient farms of the mixed agriculture type, both men and women were needed for clearly delineated tasks (Gielen 1989; Heuvel 1927). The opposite may be true for workers' sons in commercialised regions, as they could have combined staying at home with working on nearby farms; however, workers' daughters in the commercialised regions may have left earlier for domestic service.

Apart from the type of agriculture, we have to take into account the prevailing inheritance rules regarding land. In some regions, land was never divided, making it more difficult for other children than the successor to stay. In several European regions, impartible inheritance has been associated with strong out-migration (Augustins 2002; Berkner \& Mendels 1978; Wegge 1999). Depending on the wealth of the parents, non-inheriting sons could leave home to enter higher education (Dribe 2000). Children could make a favourable match and join shares with their future spouse to start a new household (Kok et al. 2010). As patrilocal marriages were often the rule, this meant that farmers' daughters were often spread over a larger area than sons (Egerbladh, Kasakoff \& Adams 2007; Kok \& Bras 2008). In some regions of Europe, strict partibility was related to a specific mobility pattern, as children had to find means to enlarge their small allotment, e.g. by working as a farm hand, by renting land, or by marrying someone (often a relative) with land in order to join plots (Béaur 2004; Berkner \& Mendels 1978; Brettell 1987). We hypothesize that in areas with partibility of land, youths, from farmer and farmworker families alike, may have participated more in circular (service) migration, but made a final move from home later than in regions with impartibility, in which most of the children would have to leave the family land eventually.

The feasibility of a future in farming has to be contrasted to the desirability and feasibility of a career outside of farming, either in cities or in areas where other industries such as textile or mining offered job opportunities. Most parts of the Netherlands provided good opportunities to work outside of farming, especially the western parts of the province of Friesland, western Overijssel, the eastern parts of Drenthe, and parts of central North Brabant. Proximity to such regions has to be taken into account, but also the amount of social capital that families might have had. The presence of family members or at least the experience and knowledge of kin who had been to such places, makes a move away from agriculture less costly and less risky (Blaauboer 2011; Bras \& Neven 2007; Kesztenbaum 2008). We assume that in rural regions with more alternative employment, children, if they left home at all, were more likely to make a local move (perhaps commuting to work in industry, cf. Kok et al. 2010) or move to a neighbouring city.

The feasibility of a future in farming changed for farmers' children during the studied period and prospects differed greatly between regions. Both dairy farming and floriculture were lucrative due to favourable export possibilities, but grain cultivation suffered from competition on the world market. The children born between 1850 and 1870 were probably the least affected by the crisis which struck Dutch agriculture after about 1880. However, these cohorts certainly felt its effects. The massive import of cheap cereals from North America, Russia and Argentina threatened the livelihood of many farmers and workers in the grain-growing regions. Many people from these regions either emigrated or moved to the booming cities in the western parts of the Netherlands. Also, many farmers switched to dairy farming which put pressure on the prices and the livelihoods in this sector as well. Farmers in horticulture as well as the farmers in the sandy soil regions practicing mixed agriculture were affected less strongly by the crisis (Knippenberg \& de Pater 1988). Accordingly, in the sandy east and south, the old three-field system of mixed agriculture (including animal husbandry and grain growing) prevailed. Here, labour intensification, the use of fertilisers as well as land reclamation made it possible to remain in agriculture longer, at least until after the Second World War.

The feasibility of a career outside farming was even more important for agricultural workers' children. Their future prospects were often not linked to a farming career. They were unlikely to inherit farm plots large enough to sustain a family, and they depended even more on local economies and opportunities to work as farmhands, in service, or in proto-industry. This is especially visible during the second half of the nineteenth century in the eastern Dutch regions, such as Twente or Achterhoek, where workers' children were kept home longer. In these areas, many workers, and especially former peasants, rented and cultivated small plots of land for saving household money and as an economic backup (Hendrickx 2003). These families often developed specific forms of labour division between agriculture and industry. Among those families primarily active in agriculture, children often worked in textile factories while the parents worked the land (Hendrickx 2003). When the commercialisation and mechanisation in agriculture, and growing proto-industry, improved agricultural productivity, it increased smallholders' and other farmers' dependencies on their own families, in combination with non-resident wage labour (Hendrickx 2003). With growing part-time employmentin proto-industry, such as weaving or (after 1830) cotton cloth in the Eastern Dutch regions of Twente, it was possible for smallholders and day labourers to more easily find work and gain extraincome (Hendrickx1993,2003; Mastboom 1996). Accordingly, during the second 
half of the nineteenth century, working on a farm or in proto-industry nearby probably made it possible for workers' children to stay longer in their parental homes. We expect workers' children to have remained in the vicinity of their parents when the occupational structure was more diversified and the likelihood of finding other work was greater (Bras \& Kok 2004). However, keeping workers' children at home was not only influenced by family economy and working opportunities in- and outside of agriculture. Additionally, according to Paping (2004), working-class families gradually became influenced by the emerging (middle-class) family ideals, encouraging parents to allow their children more time for play and school. Their increased living standards made this possible.

Who were moving where? What do the destinations tell us about the weight of family and contextual factors in the decision-making process? Staying or moving to a nearby location may indicate the possibility - or at least an expectation - to pursue a career in farming. Children departing for cities were most likely to embark on a different career than their fathers, because moving to a city most likely indicated a farewell to farming. According to Long (2005), movers to cities were always positively selected; they had the skills to become successful in urban careers. But there may have been 'intervening opportunities' in the local economy (Stouffer 1940). Long distance rural migration (in which we have included emigration) may lie between these options. Studying workers' and farmers' children's migration destinations, as they interact with local contextual and family factors, may reveal to what extent these children embarked on different careers than agricultural work. From the last quarter of the nineteenth century, the age at first marriage declined (van Poppel 1992), and we can expect children to have experienced again an earlier exit from home. However, the economic crisis in the 1930's, affecting the children born after 1910, might have again reduced migration - at least to cities - as the demand for urban employment was strongly reduced. In the middle of the twentieth century, the traditional socialisation of farmers' children - rearing them to become farmers themselves began to be perceived as problematic. There was simply no more farming land available, and the remaining farmers needed fewer hands. Emigration or retraining of redundant farmers' children for other career opportunities were seen as the only options (Hofstee 1950). Accordingly, for the beginning of the twentieth century we would expect a large share of farmers' children to have performed long distance moves.

\section{DATA, METHODS AND VARIABLES}

In order to study the migration behaviour of Dutch rural youths within their family and regional contexts, we need both life course data on the children themselves, as well as on their families. In addition, we need socio-economic information on the communities and the regions to assess the importance of factors pushing children to move away from home, to decide between destinations, or, on the contrary, to remain at home. The life course data are provided by the Historical Sample of the Netherlands (HSN), more specifically the Data Set Life Courses Release 2010.01 (Mandemakers 2000; 2006). The contextual information was based on several sources which could be linked to the life courses by way of the location data from the HSN dataset. Table 1 provides summary statistics of the data for all of our dependent and control variables.

\subsection{HISTORICAL SAMPLE OF THE NETHERLANDS (HSN)}

Based on arandom sample of birth certificates from 1812-1922 $(n=78,000)$, the HSN containsstandardized information on the life courses of a representative portion of the Dutch nineteenth- and twentieth-century population (Mandemakers 2000; 2006). These life courses were collected from the Dutch population registers which were introduced in 1850 for the whole of the Netherlands. The Dutch population registers allow us to trace persons from the cradle to the grave, at least for those who did not leave the Netherlands. All changes occurring in the household were recorded in the register. New household members arriving after the registration had started were added to the list of individuals already recorded, and those who moved out or died were deleted with reference to place and date of migration or date of death. Thus, families and individuals can be followed for a long period. In most municipalities, the registers cover a time span of ten years between the censuses, with new registers starting after each decadal census. Population registers remained in use until 1940, although in the medium-sized and large municipalities a new form of continuous registration was introduced from about 1910 onwards. This system consisted of single sheets, or so-called family cards. Thus, in these larger municipalities the registration unit was no longer the household, but instead the family (Gordon 1989; Kok 2006). 
Our period of research lasts from 1850 till 1940. We start observation of Research Persons (from here called RPs) at age 12, ignoring possible individual migration before that age. The end of observation can be death, the migration of the family (and failure to observe the family in the next locality), the year 1940, or 'administrative removals'. The end of an entry in a population register is not always given. We have used several ways to estimate the end of observation, in particular by way of making use of the chronologic order in the registrations. For a discussion of the used estimation methods, cf. Mandemakers (2006).

Thus, the HSN provides us with information on occupations, religion, births, deaths and marriages, and place and date of provenance and destination of the sampled RPs and all his/her household members. The mentioned release includes that part of the HSN which has been completed with information from the population registers, pertaining to RPs born between 1850 and $1922(n=36,406)$ (Kok, Mandemakers \& Mönkediek 2014).

\subsection{HSN - SELECTION CRITERIA}

Our study focuses on the final individual move from the parental home of RPs aged 12 to 30 years. This means that we do not treat family migration as an event of interest. Also, we ignore temporary migrations after which the RP returned home. We assume that final moves from home better reflect decisions to seek a career within or outside one's rural surroundings, compared to temporary moves. Temporary moves are not suited for this purpose, as they include migrations to reside with kin (which happened in times of family crises) and migrations to enter boarding school or military service. Observing RPs up to age 30 means that we include a large number of children who depart at marriage. Our analysis focuses on children of farmers or agricultural workers from rural areas in the Netherlands. Urban localities are thus excluded, leaving us with 11,637 cases. We restricted the analysis to those children who have been observed at least since the age of 12 and at that point were living in the parental family - in order not to miss any events of interest (excluding 43 cases). Moreover, we excluded children of agricultural workers or farmers who were not at risk of experiencing a last own migration event after the age of 12 because they were lost from observation or died before study entry $(3,289$ cases). Applying all of these selection criteria finally leaves us with 8,338 cases (4,252 sons and 4,086 daughters). In the analysis this number is further reduced to 4,073 sons and 3,898 daughters due to variable non-response.

For some of our cases, the observation window ended before the age of 30. Accordingly, these cases are right-censored. Right censoring is not necessarily a problem as long as it occurs randomly (Cleves, Gutierrez, Gould, \& Marchenko 2010). In cases in which right censoring is attributed to RPs having died before the end of the observation window (531 cases), it is not problematic because we observed RPs' whole life period. In our dataset right censoring partly also occurred because RPs (1,074 cases) were simply not followed anymore. In many cases this right censoring occurred jointly for RPs and their fathers, indicating that the register records for whole families ended.

\subsection{DEPENDENT VARIABLES AND METHODS OF ANALYSIS}

\subsubsection{LEAVING HOME (EVENT HISTORY ANALYSIS)}

We define leaving home and thus 'migration' as a change in official residence. In the dataset this was identified by a change in the address within a municipality, if a child left the parental home or moved to another municipality. We considered all moves provided they were deemed important enough to be declared to the officials. Our data is clustered; the individuals are nested in communities which are grouped into 42 macro socio-economic regions. Individuals clustered in groups or regions tend to be more similar. This leads to the problem that within regression estimation error terms can no longer be assumed to be distributed independently anymore (Cameron, Gelbach \& Miller 2011). We therefore need to correct the estimated error terms using clustered robust error variance for the highest level of clustering. In our case the highest level of clustering is at the 42 socio-economic regions. Due to our relatively large number of clusters, we expect consistent estimates (Wooldridge 2003). We test the effects of our covariates on the timing of leaving the parental home using the Cox model (Cox 1972). This semi-parametric event history model leaves the baseline hazard rate unspecified and assumes proportional hazards across sub-groups of individuals (Cleves et al. 2010; Cox 1972). To test this model specification, we have derived the Schoenfeld residuals and tested the null-hypothesis that there is no change in the coefficients of the covariates over time $(t)$ - in our case relating to personal time (Cleves et al. 2010). Inspecting the results revealed that the proportional hazard assumption (PHA) was not 
met by all independent variables in our models. Taking into account that our covariates are time-invariant, the observed significant interactions of our independent variables with $t$ (personal time), indicated time dependent coefficients which we need to consider in our models (Cleves et al. 2010). We do so via the inclusion of the interactions between the time-varying coefficients and $t$ into our Cox models. While the hazard ratios of the variables can be interpreted as time-constant effects, their interactions with $t$ represent the changes in the hazards ratios over people's life courses.

We will run separate models for farmers' and workers' children and for boys and girls, as we expect different decision-making processes to have been at work. We hypothesize that, in general, workers' children will have left home much earlier than farmers' children and, especially, workers' daughters as one of the few options to add to family income had been to work in another household. For working-class girls, there were few incentives to stay at home and early marriage, if possible, might have been an attractive means to achieve independence.

\subsubsection{GEOGRAPHICAL MOBILITY (COMPETING RISK ANALYSIS)}

Additionally, we will compare different migration possibilities with each other in order to understand to what extent rural children's migration destinations depend on particular background factors. This seems necessary to better understand the motivations for Dutch children leaving their parental home. These multiple migration outcomes may have competed with each other and were differentiated on the basis of the distance between the place of residence and the place of destination. Apart from the reference category (0) staying in their parental household (including family migrations), children might (1) move locally (defined as moves within ten kilometres), for instance to establish a household of their own in the same locality, (2) migrate regionally to rural destinations (defined as moves to a village over a distance of more than $10 \mathrm{~km}$, including emigrations), or (3) migrate to a city and most likely leave farming (urban migration) ${ }^{1}$. Without specification, using the event history analysis approach would normally only contrast one of these migration destinations, such as moving to a city, with the reference category of 'stayers'. Doing so would assume that persons who actually experienced a competing migration event, such as moving to another region, stay at risk to experience an event of interest, such as moving to a city. The underlying hazard rate is thus supposed to be independent from competing migration possibilities (Gooley, Leisdenring, Crawley \& Storer 1999). This assumption is problematic because this might not always be the case, and the event of interest might be affected by the competing migration event that had already occurred. Instead, the hazard rates of the different migration destinations seem to depend on each other (Kok et al. 2014).

To account for the different competing migration outcomes and their mutual dependence, we run a competing risk event history analysis applying the semi-parametric model developed by Fine and Gray (1999). This model assumes that the sub-distribution hazards $(\mathrm{SH})$ are proportional. We tested the event specific hazards (ESH) for being proportional or not, via visual inspection of separate log-log plots for each of our included explanatory variable for each migration event separately (Cleves et al. 2010). The graphical inspection revealed deviations from the proportional hazard assumption for most of our explanatory variables. However, the standard modelling approach, assuming proportional event-specific hazards (ESH), misspecifies the proportional sub-distribution model (SH). Even in the case that non-proportional sub-distribution hazards (SH) are present, our different models nevertheless offer a summary analysis of the estimates representing time-averaged hazard ratios, also called the least false parameter (Beyersmann, Latouche, Buchholz \& Schumacher 2009; Grambauer, Schumacher \& Beyersmann 2010; Kok et al. 2014).

Using this model we study the incidence of the different migration events being dependent on certain contextual and individual characteristics; hence we test our hypothesis via analysing the effects of our covariates on the cumulative incidence function (CIF) (Figure 3). The CIF is a function of all sub-hazard rates and thus takes failures of competing risks into account. In our final models, the estimated sub-hazard ratios are reported. These can be interpreted in a similar way as 'normal' Cox regression hazard ratios (Kok et al. 2014).

We will again run separate models for farmers' and workers' children and for boys and girls, as we expect again different decision-making processes having been at work, having led children to choose different migration destinations.

$1 \quad$ Once children moved to an urban locality any migration within this urban locality is regarded and coded as urban instead of local migration. 


\subsection{CONTEXTUAL DATA}

All locations were coded according to the Amsterdam code which identifies all Dutch municipalities that existed since 1812 (Van der Meer \& Boonstra 2006). We calculate the distance between the municipalities as the number of kilometres between the centres of the municipalities. The calculation was based on the geographical coordination system that is mapped over the Netherlands, based on trigonometrical measurements. Each municipality has its own set of $X Y$-coordinates from which it is possible to calculate distances (Law of Pythagoras). Although travel roads do not follow a straight line, by around 1880 there already existed a serious railway network connecting most parts of the country within 24 hours; and during the whole nineteenth and twentieth century there were a lot of steamships connecting all harbours around the Zuiderzee, a large inland sea (see the maps in Knippenberg \& De Pater 1988). To overcome the first disadvantage we have made a separate category for distances lower than ten kilometres.

For the distinction between urban and rural municipalities we follow Kooij (1985, pp. 111-113). He defines urban communities as places with over 10,000 inhabitants and with less than $2.5 \%$ percent of the population employed in the agricultural sector. In our analysis we used the outcomes of the 1899 census: 53 municipalities took the urban threshold, including about $51 \%$ of the total population.

Linking the places of original residence provided in the HSN with data on types of agriculture and regional statistics enables us to additionally account for the regional and community context of the farmers' children. As described in the introduction, these contexts constitute factors either pushing out or restraining farmers' children to their communities. We created five contextual variables: agricultural system, partibility of farm land, population density, alternative employment, and worker-owner ratio in agriculture to indicate the importance of family firms.

Agricultural system. Following Kok et al. (2014), we distinguished between four categories of agricultural systems (floriculture, dairy farming, grain cultivation, and mixed agriculture) which we derived from the 12 types specified in an agricultural survey of 1874 (Knippenberg \& de Pater 1988; Verslag van den Landbouw 1875). We have coded each municipality according to whether the dominant agricultural type in a given community was floriculture/horticulture, grain cultivation, dairy farming or mixed agriculture. In doing so, we ignore the important rural dynamics in the decades after 1875 (Bieleman 2008), thus we can only claim to have captured the initial situation. The types reflect the regional soil conditions, but also the labour intensity and integration of farming in the market in 1874.

Partibility of farm land. Our indicator of the way farm land was inherited is based on contemporary surveys of local inheritance practices. We use a nationwide 1949 report on the question whether farm land was divided at all and have combined this information with an earlier report (1915) (Baert 1949; Klep 2010; Van Blom 1915) before we coded each municipality. This indicator still leaves much to be desired; however, based on this information, we have divided the country into regions where farm land could be divided (at least in the first half of the twentieth century) and regions where land was kept intact. In the latter case, the surveys do not give conclusive evidence whether primo- or ultimogeniture prevailed, nor to what extent women could be the sole successors to a farm. In addition, we are aware that the information may not accurately represent the situation before the Agricultural Depression.

Population density. To account for population pressure on the migration behaviour of farmers' children, we calculated the population density of each municipality for the years 1859, 1889, and 1930 using the Historical Database of Dutch Municipalities (Beekink, Boonstra, Engelen \& Knippenberg 2003). The population density was derived by dividing the number of inhabitants by the surface area. We expect that the more populated an area was, the heavier the pressure for farmers' children to migrate. However, for workers' children the opposite may be true as the employment opportunities that come with high population density might give them an incentive to remain in the locality.

Alternative employment. To account for opportunities for children to leave the agricultural sector while staying in the region, we calculated (male and female) employment outside of agriculture per region (1889, 1899 and 1930). We have operationalised this alternative employment as the percentage of men working (in 1889, 1899 or 1930) in non-agricultural occupations in municipalities with more than 20,000 inhabitants within the economic-geographic region of the municipality where the farming family resided. Because the censuses provide this information only for communities with more than 5,000 inhabitants we could not calculate this on the local level (Kok et al. 2014).

Worker-owner ratio. The extent to which, in a given area, farms were run by family members versus hired employers may explain differences in leaving home and migration between these groups. Based 
on the occupational census of 1930, we calculated the worker-owner ratio in each region which gives the number of owners and workers per economic sector per economic-geographic region. The regional classification was developed by Dutch Statistics in 1921 and was published in connection with the outcomes of the 1920 census. The 42 regions were distinguished on the basis of the provincial borders and economic specialisation. In general, each province was divided into industrial, commercial and rural regions (De Bie 2009). The worker-owner ratio does not seem to be related to partibility of land, but differs (as expected) among agricultural types. The average worker-owner ratio is lower in 'mixed' agriculture (mean: 1.275, std-err.: 0.007), suggesting a reliance on family labour in more traditional farming. Conversely, in grain cultivation areas with a high average worker-owner ratio can be observed (mean: 2.055, std-err.: 0.014), while it is even higher in labour intensive regions of floriculture (mean: 2.348, std-err.: 0.015). For dairy farming the average worker-owner ratio is much lower (mean: 1.594, std-err.: 0.011). We expect that in regions where the worker-owner ratio is higher, workers' children are more likely to perform local moves or to not migrate at all due to better employment opportunities.

Our contextual indicators do not capture dynamic changes in regional socio-economic conditions. However, they are still able to reflect the socio-economic and agricultural differences between the studied regions since they are good approximations of the living conditions on which Dutch farmers' and workers' children based their migration decisions (path dependency). Including dynamic indicators, with multiple observations over time, would complicate our already complex models even further. However, to partly capture changes in socio-economic conditions we have divided our population into four birth cohorts (1850-1870, 1871-1890, 1891-1910, and 1911-1922). Accordingly, most of the change over time in our models relies on cohort effects.

In addition, we try to account for changes in the effects of the contextual variables over children's life courses by allowing some of these effects to vary over people's ages. Therefore, we multiply these time-invariant factors by people's ages (in months) to create time-varying covariates.

\subsection{FAMILY FACTORS AND RELIGION}

Next to the contextual variables, in our analysis we control for the effects of different family factors on the timing of leaving home and children's migration destinations. Also these family factors were partly interacted with ages to control for changes in their effects over children's life courses.

Birth order and number of brothers and sisters. The number of male and female siblings as well as the birth order might be important family factors in explaining why certain children leave home sooner or later. We expect that given the gender division of labour on most farms, farm girls were 'superfluous' when they had many sisters, and boys when they had many brothers. We expect a weaker effect from the number of siblings from the opposite sex. In workers' families the pressure of having multiple siblings might have been even more acute, as children did not contribute to home production. Probably, the mother needed just one daughter to help her with the household chores. We do not expect rank order to predict timing or direction of home leaving among workers' children. With respect to agricultural families, family composition does not predict migration direction, only the likelihood of leaving home. In areas with impartible inheritance, both primo- and ultimogeniture occurred, which could also include daughters (Van Blom 1915). In the other regions as well, we expect children in the middle of the sibling order to be more likely to migrate and choose another occupation than only, first or last children. In several studies on the destinies of farmers' children, the ones in the middle were pointed out as likely migrants (Adams \& Kasakoff 1992), in others, all but only and first children (Barrera-González 1992; McQuillan 2008). Leaving agriculture for alternative careers entails making more long distance moves and more rural to urban moves, and we expect, at least, that first born sons were the least likely to make such moves.

Religion. We included the religious background to control for the distinctive cultural and demographic patterns that existed among the several religious groups in the Netherlands. We distinguished four main groups: Roman Catholics, Orthodox Protestants, Liberal Protestants and Others. The last group were mainly Jews and non-believers, a category that emerged only at the beginning of the twenties century in large quantities (Knippenberg 1992). Among farmers, 'others' were especially rare. For the distinction of the Protestants in Liberal and Orthodox groups we followed Kok and Van Bavel (2006). In general, we expect that Roman Catholics and Orthodox Protestants were more reluctant to let their children move to a city where they might be led astray by the modern life style. This might be the case especially for daughters at young ages. However, it might also be the case that some Roman Catholic children made long distance moves, as Catholic boarding schools were clustered in the southern 
regions. Overall, very little is known on religious differentials in adolescent leaving home or migration behaviour.

Table 1 Summary statistics of the data and variables

\begin{tabular}{|c|c|c|c|}
\hline Number of children & & & 8,338 \\
\hline Number (and \%) of farmers' children & & & $3,112(37.3 \%)$ \\
\hline Number (and \%) of female children & & & $4,086(49.0 \%)$ \\
\hline Number (and \%) of female farmers' children & & & $1,535(49.3 \%)$ \\
\hline Cohort & $\begin{array}{r}\text { Number (and \%) } \\
\text { of all children }\end{array}$ & $\begin{array}{l}\text { Number (and \%) } \\
\text { of female children }\end{array}$ & $\begin{array}{r}\text { Number (and \%) } \\
\text { of male children }\end{array}$ \\
\hline $1849-1870$ & $1,605(19.3 \%)$ & $780(19.1 \%)$ & $825(19.4 \%)$ \\
\hline $1871-1890$ & $2,710(32.5 \%)$ & $1,345(32.9 \%)$ & $1,365(32.1 \%)$ \\
\hline $1891-1910$ & $2,843(34.1 \%)$ & $1,351(33.1 \%)$ & $1,492(35.1 \%)$ \\
\hline $1911-1923$ & $1,180(14.2 \%)$ & $610(14.9 \%)$ & $570(13.4 \%)$ \\
\hline Migration Direction & $\begin{array}{r}\text { Number (and \%) } \\
\text { of all children }\end{array}$ & $\begin{array}{l}\text { Number (and \%) } \\
\text { ofworkers' children }\end{array}$ & $\begin{array}{l}\text { Number (and \%) } \\
\text { offarmers' children }\end{array}$ \\
\hline No migration observed (family migration) & $4,725(56.7 \%)$ & $2,979(53.5 \%)$ & $1,928(62.0 \%)$ \\
\hline Local rural migration $(<10 \mathrm{~km})$ & $2,161(25.9 \%)$ & $1,479(28.3 \%)$ & $682(21.9 \%)$ \\
\hline Rural migration $(>10 \mathrm{~km})$ & $824(9.9 \%)$ & $507(9.7 \%)$ & $317(10.2 \%)$ \\
\hline Urban migration & $628(7.5 \%)$ & $443(8.5 \%)$ & $185(5.9 \%)$ \\
\hline Agricultural types & $\begin{array}{r}\text { Number (and \%) } \\
\text { of all children }\end{array}$ & $\begin{array}{l}\text { Number (and \%) } \\
\text { ofworkers' children }\end{array}$ & $\begin{array}{l}\text { Number (and \%) } \\
\text { offarmers' children }\end{array}$ \\
\hline Mixed & $3,440(41.53 \%)$ & $1,887(36.31 \%)$ & $1,553(50.32 \%)$ \\
\hline Horticulture & $254(3.07 \%)$ & $166(3.19 \%)$ & $88(2.85 \%)$ \\
\hline Dairy & $1,490(17.99 \%)$ & $904(17.39 \%)$ & $586(18.99 \%)$ \\
\hline Grain & $3,099(37.41 \%)$ & $2,240(43.10 \%)$ & $859(27.84 \%)$ \\
\hline Other contextual factors & & & \\
\hline Number (and \%) of children from partible a & & & $4,936(59.2 \%)$ \\
\hline Average population density, for 70 municipa & ities (Std. Err.) & & $14.199(3.565)$ \\
\hline Average worker-owner ratio, for 41 regions & (Std. Err.) & & $1.649(0.115)$ \\
\hline Family factors & & & \\
\hline Average number of brothers (Std. Err.) & & & $1.973(0.017)$ \\
\hline Average number of sisters (Std. Err.) & & & $1.844(0.016)$ \\
\hline Number (and \%) of children without siblings & & & $803(9.6 \%)$ \\
\hline Number (and \%) of first born sons & & & $1,268(15.2 \%)$ \\
\hline Number (and \%) of last born sons & & & $1,042(12.5 \%)$ \\
\hline Number (and \%) of other sons & & & $1,942(23.3 \%)$ \\
\hline Number (and \%) of first born daughters & & & $1,139(13.7 \%)$ \\
\hline Number (and \%) of last born daughters & & & $1,023(12.3 \%)$ \\
\hline Number (and \%) of other daughters & & & $1,924(23.1 \%)$ \\
\hline Religion & & & $\begin{array}{r}\text { Number (and \%) } \\
\text { of all children }\end{array}$ \\
\hline Catholic & & & $2,404(28.83 \%)$ \\
\hline Liberal Protestant & & & $3,513(42.13 \%)$ \\
\hline Orthodox Protestant & & & $1,556(18.66 \%)$ \\
\hline Other/Non & & & $865(10.37 \%)$ \\
\hline
\end{tabular}




\section{LEAVING HOME}

We start our analysis with the graphical inspection of the survival rates of farmers' and workers' children of leaving the parental home. Figures 1 and 2 support our assumption that workers' children left home much earlier than farmers' children (although farmers' sons made their final moves slightly faster when they were young). As expected, this is especially the case for workers' daughters who not only moved out faster than peasant daughters, but also faster than their male counterparts. Compared to their male counterparts, about $80 \%$ of all workers' daughters up to age 30 left the parental household for a first migration (sons around $68 \%$ ). While about $59 \%$ of workers' daughters and $48 \%$ of the workers' sons left their parental home once and for all during the same window.

In general, farmers' children often remained in their parental home and had the highest survival rate. Nevertheless, despite staying much longer in their parental homes than workers' daughters (Figure 1), daughters of farmers still move out more often than farmers' sons (Figure 2). Until the end of the observation window (age 30) only 50\% of the farmers' daughters had not yet made a definite move from home - for farmers' sons this percentage of 'stayers' was much higher (61\%). Instead, for a larger share of children the observed migrations turned out to be temporary moves. Children of farmers and children of workers often returned to their parents' house at a later stage in life. This becomes obvious when we compare children's first migrations that were followed by return migrations (temporary moves) with their observed final moves of leaving home. For example, until the age of 25 about $47 \%$ of workers' sons left their parental home temporarily and returned afterwards (based on first migrations). However, only $26 \%$ of the workers' sons finally left their home once and for all by the age of 25 .

Our results thus indicate a complex picture of the leaving home process of Dutch rural youths. Leaving home was not a singular event which resulted in a large share of children setting up a household on their own. Instead, our descriptive results suggest that leaving home often resulted in return moves to the parental house. At the same time, we find important differences in leaving home between social groups, as well as between sons and daughters.

Figure 1 Survival function of remaining in the parental home, for daughters

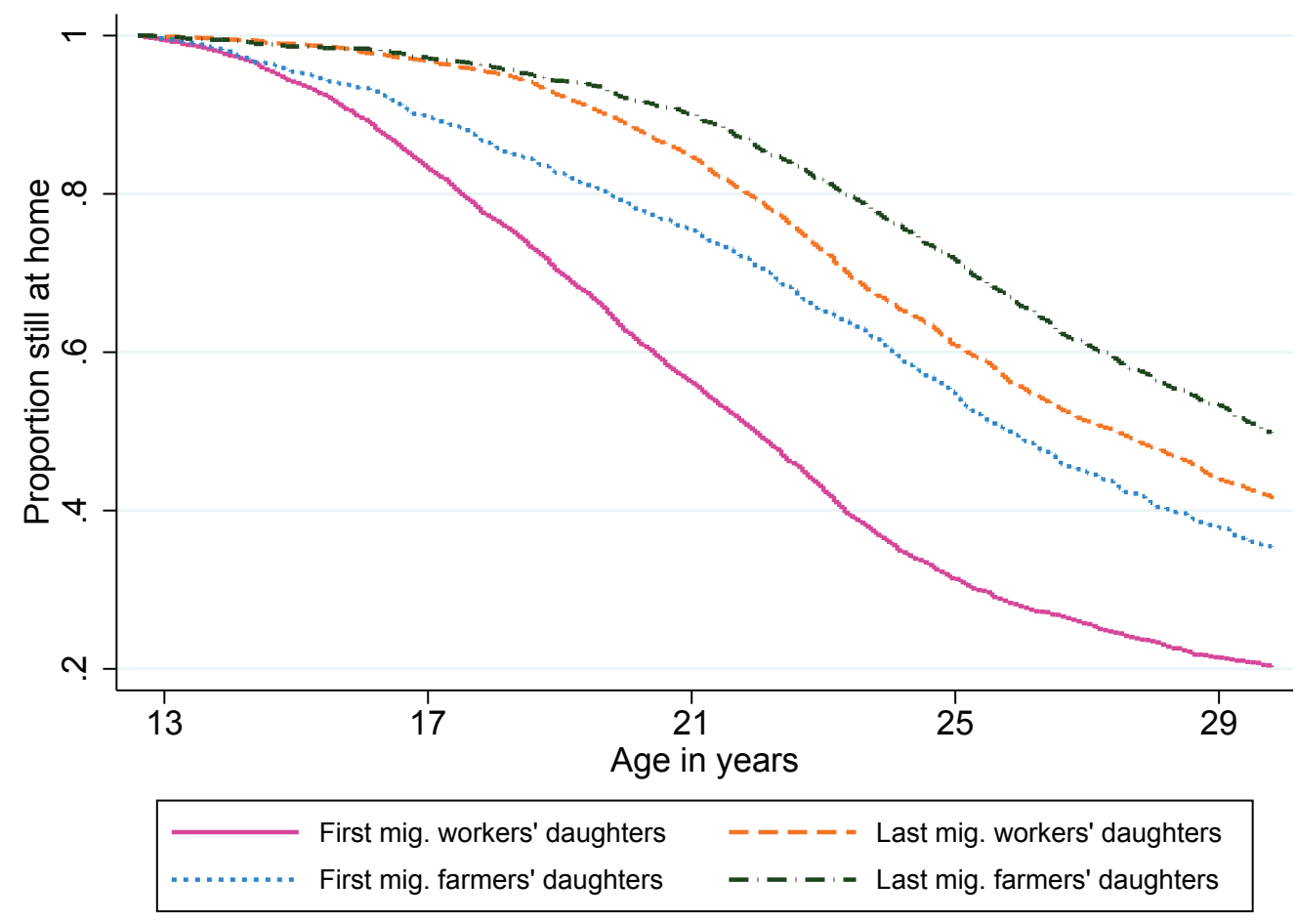


Figure 2 Survival function of remaining in the parental home, for sons

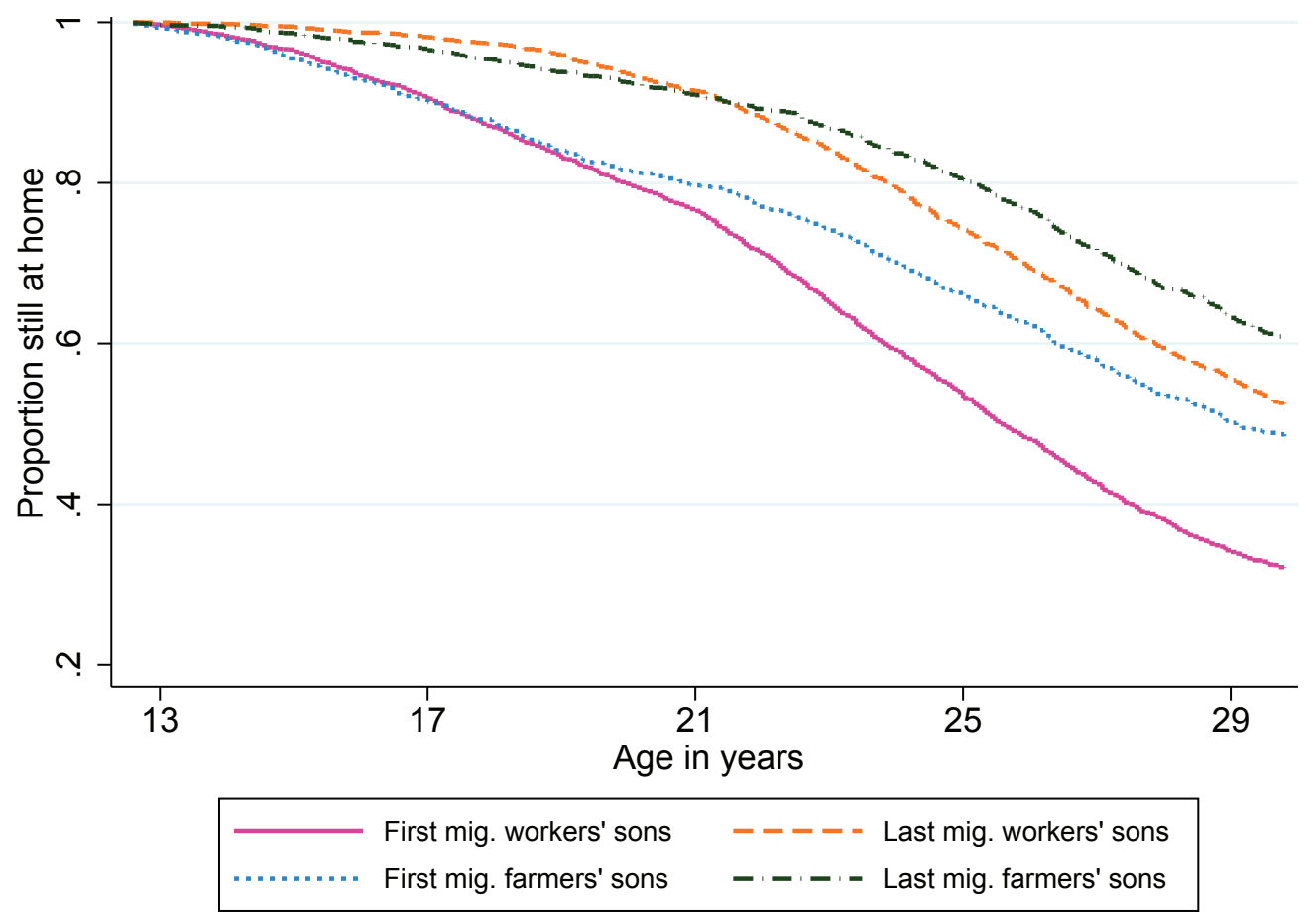

Which factors influenced rural youths to depart from home? In table 2, we present the outcomes of the Cox regression on the last move from home of workers' children; farmers' children are examined in table 3. Model 2.1 (sons) and model 2.3 (daughters) in table 2 show the effect of the independent variables without interactions, while interactions are included in models 2.2 and 2.4. The presented effect coefficients reflect hazard ratios. Values greater than one reflect an increase in the chances of leaving home, and values lower than one relate to lower chances of leaving home. As demonstrated by the results, for sons and daughters leaving home occurred earlier in the younger birth cohorts, which is probably a reflection of higher marriage frequency and lower ages at marriage in the working classes in the first half of the twentieth century. Religious affiliation and most local contextual factors turned out to have no significant effects. Only for working-class girls impartible inheritance rules led to leaving home earlier than girls in regions with partibility inheritance of land. Perhaps this implies that farms were larger in the first area, offering more employment for live-in servants.

Concerning the agricultural systems, we do see that workers' sons in regions with the most commercialised agriculture, especially flori- and horticulture $(\mathrm{HR}=0.334)$, were more likely to stay home. The salaries they could earn on nearby farms might have led to parental pressure to remain at home. Though, this effect weakened over children's life courses (see time-dependent effect of horticulture: $H R=1.003$ ), and older workers' sons were slightly less likely to remain in their parental homes than younger ones. A significant effect of the agricultural system on the event of leaving their parental home is also observed for girls in the flori- and horticultural regions (model 2.3). As indicated by the time-varying $(H R=1.004)$ and the time invariant effect $(H R=0.279)$, similar to workers' sons, young girls in horticulture regions tended to leave home later, while older girls leave their parents' home faster. As these regions were also in the vicinity of large cities, it is likely that older girls went into domestic service in urban households.

Moreover, model 2.1 shows that the departure of workers' sons is partly affected by their sibling order. Being the first born son strongly delayed the final moves of leaving home ( $H R=0.471)$, while this effect weakened again over their life course (time varying-coefficients: HR=1.002). As demonstrated by the effects of number of sisters (model 2.3), girls were also pushed out by sisters ( $H R=1.046)$ which confirms contemporary reports and earlier findings that in working-class households just one grown-up girl was needed in the household (Bras \& Kok 2004). Nevertheless, regarding the effects of having siblings, we have to be aware that different agricultural systems had different gender divisions of labour, leading to different sibling pressures on leaving home per region. Interestingly, when we interact type of agriculture with having siblings (model 2.4), we find no significant interaction terms (including the effect of 'sisters' representing the effects in mixed agricultural areas) which would support the idea that sisters pushed 
each other out of the household. For workers' sons (model 2.2), having brothers led to earlier departures in the horticulture and mixed farming regions, whereas in the grain cultivating regions the opposite was true. Concerning these results, it is difficult to say what mechanisms were at work here. Maybe the income pooling in the horticulture region did allow for earlier marriage of workers' sons. In the next section, we try to find out what kind of move (e.g. leaving agriculture for city life) was responsible for the observed outcomes in order to better understand the ongoing processes.

Table 2 Leaving home of workers' children, by gender (hazard ratios from a Cox model)

\begin{tabular}{|c|c|c|c|c|}
\hline \multirow[t]{2}{*}{ Variables } & \multicolumn{2}{|c|}{ Sons } & \multicolumn{2}{|c|}{ Daughters } \\
\hline & Model 2.1 & Model 2.2 & Model 2.3 & Model 2.4 \\
\hline $\mathrm{N}$ brothers & 1.024 & $1.058^{*}$ & 1.001 & 1.020 \\
\hline $\mathrm{N}$ sisters & 0.984 & 0.954 & $1.046^{* *}$ & 1.029 \\
\hline Firstborn & $0.471 *$ & $0.471 *$ & $0.365^{* *}$ & $0.367^{* *}$ \\
\hline Lastborn & 0.901 & 0.897 & 0.941 & 0.941 \\
\hline \multicolumn{5}{|l|}{ Religion } \\
\hline Catholic & REF. & REF. & REF. & REF. \\
\hline Liberal Prot. & 1.111 & 1.111 & 1.039 & 1.036 \\
\hline Orthod. Prot. & 1.160 & 1.171 & 0.948 & 0.948 \\
\hline Oth./Non & 1.035 & 1.041 & 1.063 & 1.059 \\
\hline Impartibility & 1.048 & 1.052 & $1.150^{*}$ & $1.151^{*}$ \\
\hline Alt. Employ. & 1.003 & 1.003 & 0.998 & 0.998 \\
\hline Pop. Density & 1.000 & 0.999 & 1.000 & 0.999 \\
\hline $\begin{array}{l}\text { Worker/Owner } \\
\text { Ratio }\end{array}$ & 1.086 & 1.084 & 0.979 & 0.982 \\
\hline \multicolumn{5}{|l|}{ Agric. System } \\
\hline Mixed & REF. & REF. & REF. & REF. \\
\hline Horticulture & $0.334^{*}$ & $0.125^{* * *}$ & $0.279 * * *$ & $0.280 * * *$ \\
\hline Dairy & 0.877 & 0.812 & 0.958 & 0.909 \\
\hline Grain & $0.774 * *$ & 0.868 & 1.025 & 1.061 \\
\hline \multicolumn{5}{|c|}{ Cohort } \\
\hline $1850-1870$ & REF. & REF. & REF. & REF. \\
\hline $1871-1890$ & 1.070 & 1.063 & $1.211^{*}$ & $1.213 * *$ \\
\hline 1891-1910 & $1.612 * * *$ & $1.618 * * *$ & $1.772 * * *$ & $1.771 * * *$ \\
\hline 1911-1922 & $2.585^{* * *}$ & $2.605^{* * *}$ & $2.923 * * *$ & $2.920 * * *$ \\
\hline $\begin{array}{l}\text { N Brothers } x \\
\text { Horticulture }\end{array}$ & & $1.246 * * *$ & & 1.007 \\
\hline$N$ Brothers $x$ & & 0.996 & & 0.987 \\
\hline Dairy & & & & \\
\hline $\begin{array}{l}N \text { Brothers X } \\
\text { Grain }\end{array}$ & & $0.894 * *$ & & 0.962 \\
\hline N Sisters $x$ & & 1.021 & & 0.983 \\
\hline Horticulture & & 1050 & & 1012 \\
\hline $\begin{array}{l}\text { Dalry } \\
\text { N Sisters } x\end{array}$ & & 1.057 & & 1.022 \\
\hline \multicolumn{5}{|c|}{$\begin{array}{c}\text { Time varying coefficients } \\
\text { (interactions with time }=\text { age in month) }\end{array}$} \\
\hline Firstborn & $1.002^{\wedge}$ & $1.002^{\wedge}$ & $1.004^{* *}$ & $1.004^{* *}$ \\
\hline Horticulture & $1.003^{*}$ & $1.004 * *$ & $1.006^{* * *}$ & $1.006^{* * *}$ \\
\hline Wald Chi (df) & $170.00(19)$ & $1726.84(25)$ & $878.03(19)$ & $4924.18(25)$ \\
\hline $\mathrm{N}$ & 2567 & 2567 & 2429 & 2429 \\
\hline $\mathrm{N}$ event & 1057 & 1057 & 1262 & 1262 \\
\hline
\end{tabular}

$\wedge p<0.10,{ }^{*} p<=0.05, * * p<=0.01,{ }^{* * *} p<=0.001$ 
Table 3 Leaving home of farmers' children, by gender (hazard ratios from a Cox model)

\begin{tabular}{|c|c|c|c|c|}
\hline \multirow[t]{2}{*}{ Variables } & \multicolumn{2}{|c|}{ Sons } & \multicolumn{2}{|c|}{ Daughters } \\
\hline & Model 3.1 & Model 3.2 & Model 3.3 & Model 3.4 \\
\hline $\mathrm{N}$ brothers & 1.029 & $1.059^{\wedge}$ & 1.009 & 0.994 \\
\hline $\mathrm{N}$ sisters & 0.949 & 0.988 & 1.041 & $1.105 * *$ \\
\hline Firstborn & $0.225^{*}$ & $0.231^{*}$ & $0.202 * *$ & $0.207^{* *}$ \\
\hline Lastborn & $0.383^{\wedge}$ & $0.383^{\wedge}$ & $0.682 * * *$ & $0.679 * * *$ \\
\hline \multicolumn{5}{|l|}{ Religion } \\
\hline Catholic & REF. & REF. & REF. & REF. \\
\hline Liberal Prot. & 0.935 & 0.937 & 0.992 & 0.981 \\
\hline Orthod. Prot. & $1.302^{\wedge}$ & $1.324^{*}$ & 0.974 & 0.977 \\
\hline Oth./Non & 0.841 & 0.844 & 0.897 & 0.912 \\
\hline Impartibility & 1.013 & 1.001 & 1.056 & 1.064 \\
\hline Alt. Employ. & 0.995 & 0.995 & 1.006 & 1.005 \\
\hline Pop. Density & $0.934^{*}$ & $0.931^{*}$ & $0.973^{\wedge}$ & 0.973 \\
\hline $\begin{array}{l}\text { Worker/Owner } \\
\text { Ratio }\end{array}$ & $1.234^{*}$ & $1.217^{*}$ & 0.936 & 0.937 \\
\hline \multicolumn{5}{|l|}{ Agric. System } \\
\hline Mixed & REF. & REF. & REF. & REF. \\
\hline Horticulture & 0.877 & $1.564^{*}$ & 0.903 & 0.965 \\
\hline Dairy & 1.175 & 1.304 & 0.853 & 1.023 \\
\hline Grain & 0.899 & 1.225 & 0.911 & 1.084 \\
\hline $1850-1870$ & REF. & REF. & REF. & REF. \\
\hline $1871-1890$ & 1.163 & 1.159 & $1.450 * *$ & $1.448 * *$ \\
\hline $1891-1910$ & $2.010 * * *$ & $1.991 * * *$ & $2.082 * * *$ & $2.068 * * *$ \\
\hline 1911-1922 & $2.736 * * *$ & $2.703^{* * *}$ & $3.786 * * *$ & $3.703 * * *$ \\
\hline $\begin{array}{l}\text { N Brothers } x \\
\text { Horticulture }\end{array}$ & \multicolumn{2}{|r|}{0.977} & & 1.020 \\
\hline $\begin{array}{l}\text { N Brothers X } \\
\text { Dairy }\end{array}$ & \multicolumn{2}{|r|}{0.949} & & 1.046 \\
\hline $\begin{array}{l}\text { N Brothers x } \\
\text { Grain }\end{array}$ & \multicolumn{2}{|r|}{0.962} & & 1.012 \\
\hline $\begin{array}{l}\text { N Sisters x } \\
\text { Horticulture }\end{array}$ & \multicolumn{2}{|r|}{$0.783^{* * *}$} & & 0.944 \\
\hline $\mathrm{N}$ sisters $\mathrm{x}$ & \multirow{2}{*}{\multicolumn{2}{|c|}{1.003}} & & 0.870 \\
\hline Dairy & & & & \\
\hline N Sisters $x$ & \multicolumn{2}{|r|}{$0.885^{\wedge}$} & & $0.905^{\wedge}$ \\
\hline \multicolumn{5}{|c|}{$\begin{array}{l}\text { Time varying coefficients } \\
\text { (interactions with time = age in month) }\end{array}$} \\
\hline Firstborn & $1.005^{*}$ & $1.005^{\wedge}$ & $1.005 * *$ & $1.005^{* *}$ \\
\hline Lastborn & $1.003^{\wedge}$ & $1.003^{\wedge}$ & & \\
\hline Wald Chi (df) & 223.32 (19) & $36958.80(25)$ & $485.16(18)$ & 8650.33 (24) \\
\hline $\mathrm{N}$ & 1509 & 1509 & 1479 & 1479 \\
\hline N event & 509 & 509 & 634 & 634 \\
\hline
\end{tabular}

$\wedge p<0.10,{ }^{*} p<=0.05, * * p<=0.01, * * * p<=0.001$ 
The Cox regression models for farmers' children (table 3 ) show again strong period effects, which mightindicate that the viability of family farms, or the ability of parents to retain their children, increasingly came under pressure. In addition, for farmers' children, the contextual factors seem to have affected the feasibility of a farming career. However, these effects work in partly unexpected directions. Sons were more likely to stay in municipalities with a high population density ( $\mathrm{HR}=0.934)$, whereas we had assumed the opposite. As expected, a higher worker-owner ratio, indicating less reliance on family labour, stimulated sons to leave their parental home earlier $(\mathrm{HR}=1.234)$. Also sons of orthodox protestant farmers made the final exit from home earlier than sons of Roman Catholic ones (see model 3.2). For daughters we do not observe any of these contextual factors having been of importance.

What about our family factors? Regarding birth order, we find a strong delaying effect of being the first born son or daughter (models 3.1 and 3.3), while model 3.3 additionally indicated that the youngest daughters of farmers were very likely to remain at home $(H R=0.682)$. Interestingly, we observe again that these effects weakened with children's age (sons: $H R=1.005$, daughters: $H R=1.005$ ). Besides this, the models 3.2 and 3.4 in table 3 show some interactions between the sibset and the type of agriculture. Surprisingly, we find that sons with many sisters tend to stay longer in the parental home in horticulture ( $H R=0.783)$ and grain regions ( $H R=0.885)$ (the second effect being by trend significant). Sons might have left early, as there were many alternative options in the regions, but a large family might have made for a successful farm, thus retaining them. In mixed agricultural regions having brothers increased the chances of leaving home (HR=1.059), while this effect is only by trend significant. Girls were needed on grain farms, but not too many. Still, the results suggest that in grain regions daughters with many sisters tended to stay longer in their parental home (HR=0.905), while sisters in mixed agricultural areas pushed each other out $(H R=1.105)$ (model 3.4).

\section{MIGRATION DESTINIES}

After we have studied differences in patterns of leaving home among workers' and farmers' children, we take a closer look at children's migration destinations. Figure 3 shows the (cumulative) hazards of experiencing a specific migration event of leaving the parental home between the ages of 12-30. The figure shows that migrating children often migrated locally (within the same rural location); the sub-hazards for rural $(>10 \mathrm{~km})$ and urban moves were much lower.

\section{Figure 3 Cumulative incidence functions for leaving the parental home}

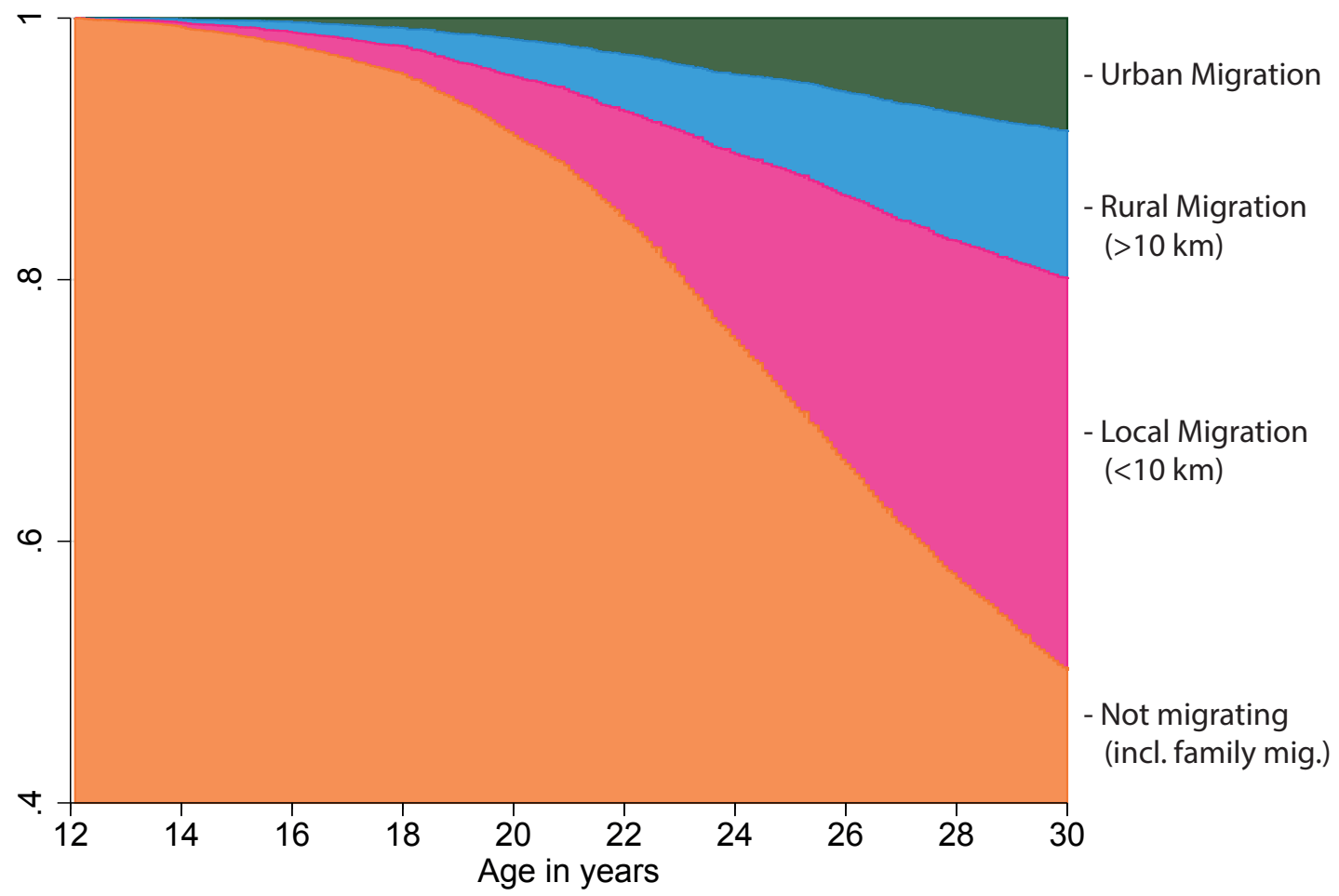


To see whether leaving home implied leaving agriculture or not, we have devised a competing risk model of migration destinations. We have tested three models: for local migration $(<10 \mathrm{~km})$, rural migration $(>10 \mathrm{~km})$ and urban migration, both for sons and daughters. The models give timing and incidence of experiencing a specific type of last migration, while contrasting it with staying at home (not migrating) or experiencing another type of migration. Table 4 shows that our understanding of leaving home is enhanced by adding the destinations to the analytical model. We see that for different destinations, different combinations of explanatory factors were responsible.

When we study period effects on different types of migration, we can see that our finding of leaving home earlier in the youngest cohorts in table 2 is still confirmed, and that final moves in all directions were more likely. Contextual factors, such as population density, and religion still do not play a role for the migration behaviour of workers' children. For workers' daughters we only observe a significant effect of opportunities of alternative employment in a region on their likelihood to migrate locally $(<10 \mathrm{~km})$, while making intra-rural moves over longer distances $(>10 \mathrm{~km})$ seem to have been related to the partibility of land in the region for workers' sons (the effect is only by trend significant). However, regarding the different agricultural systems and our family factors, we observe again significant effects of families' compositions among different agricultural regions. For instance, workers' sons' local moves $(<10 \mathrm{~km})$ as well as migration to a city were affected by the family composition when they originated from flori- and horticultural regions. Sons in these regions were less likely to make a short distance move $(<10 \mathrm{~km})$ when they had many brothers $(\mathrm{HR}=1.383)$ or sisters $(\mathrm{HR}=1.107)$. They were very likely to leave when they came from small families (without siblings: $\mathrm{HR}=0.481$ ), while being the last born in their family reduced their chances for making intra-rural moves over longer distances $(>10 \mathrm{~km})(H R=0.720)$. In addition, workers' sons from horticulture regions were very likely to move to a city $(H R=4.219)$, except if they came from large families with multiple brothers $(H R=0.597)$ or sisters $(H R=0.515)$. The same accounts for workers' sons out of dairy farming regions who had many brothers. The high risks of male children from small families in horticulture regions to move to a city can be explained by the proximity of this region to the cities of Haarlem, Den Haag and Leiden. Moving to a city was also most likely for workers' sons born in the cohort 1891-1910 who probably benefited from the expansion of employment in cities which stalled during the Depression, leading to a lower incidence of rural-urban moves in the younger cohort.

To some extent, the picture is reversed for daughters from horticulture areas who tended to perform local migrations $(<10 \mathrm{~km})$ or performed intra-rural moves over longer distances $(>10 \mathrm{~km})$ when they had many brothers (HR=1.059). Interestingly, for workers' daughters in horticulture regions having many sisters had the opposite effect and reduced daughters chances to perform a long distance move $(>10 \mathrm{~km})$ $(\mathrm{HR}=0.528)$. A similar but reversed effect can be observed for daughters in grain cultivating regions. For these daughters, having multiple brothers decreased their chances to migrate within the region $(>10 \mathrm{~km})$ ( $H R=0.911)$, while having had multiple sisters increased their likelihood for making intra-rural moves over longer distances $(>10 \mathrm{~km})(\mathrm{HR}=1.207)$. Finally, daughters from horticulture regions that had many sisters more often migrated to a city $(H R=1.343)$.

Apart from the sibship size, birth order also played a role for workers' daughter's migration destinations. First born daughters were more likely to migrate locally $(<10 \mathrm{~km})$, while they less often migrated to a city $(\mathrm{HR}=0.774)$.

Table 5 presents the outcomes for farmers' children. Again we can see differences in the effects among migration outcomes. For example, the worker-owner ratio only positively affects the chances for farmers' sons to migrate locally $(<10 \mathrm{~km})$ or to perform intra-rural moves over longer distances $(>10$ $\mathrm{km}$ ). This probably relates again to less reliance on family labour and to better local and regional employment opportunities. Farmers' sons in municipalities with high population density were - as expected - less likely to move nearby, but we do not see an 'exodus' effect of high density. Also farmers' daughters were less likely to perform intra-rural moves $(H R=0.644)$ when they lived in municipalities with high population density. 
Table 4 Results of the competing risk models with interaction effects, differentiated for migration destination and sex, workers' children

\begin{tabular}{|c|c|c|c|c|c|c|}
\hline \multirow{3}{*}{ Variables } & \multicolumn{3}{|c|}{ Sons (Model 4.1) } & \multicolumn{3}{|c|}{ Daughters (Model 4.2) } \\
\hline & $\begin{array}{l}\text { Local } \\
\text { Migration }\end{array}$ & $\begin{array}{l}\text { Rural } \\
\text { Migration }\end{array}$ & $\begin{array}{l}\text { Urban } \\
\text { Migration }\end{array}$ & $\begin{array}{l}\text { Local } \\
\text { Migration }\end{array}$ & $\begin{array}{l}\text { Rural } \\
\text { Migration }\end{array}$ & $\begin{array}{l}\text { Urban } \\
\text { Migration }\end{array}$ \\
\hline & \multicolumn{6}{|c|}{ Individual Factors } \\
\hline $\mathrm{N}$ brothers & 1.035 & 1.028 & 1.086 & 1.001 & $1.059 *$ & 0.994 \\
\hline $\mathrm{N}$ sisters & 0.984 & 0.930 & 0.988 & 1.036 & 0.958 & 1.093 \\
\hline Firstborn & 1.003 & 0.855 & 1.056 & $1.276^{* * *}$ & 0.838 & $0.774^{*}$ \\
\hline Lastborn & 0.967 & $0.720^{*}$ & 1.023 & 0.974 & 1.002 & 0.865 \\
\hline \multicolumn{7}{|l|}{ Religion } \\
\hline Catholic & REF. & REF. & REF. & REF. & REF. & REF. \\
\hline Liberal Prot. & 1.155 & 0.992 & 0.944 & 1.024 & 1.183 & 0.890 \\
\hline Orthod. Prot. & 1.200 & 0.841 & 1.229 & 0.961 & 1.001 & 0.954 \\
\hline Oth./Non & 0.948 & 1.399 & 0.692 & 1.058 & 1.254 & 0.760 \\
\hline \multicolumn{7}{|c|}{ Regional Factors } \\
\hline Impartibility & 0.982 & $1.266^{\wedge}$ & 1.046 & 1.133 & 1.118 & 1.044 \\
\hline Alt. Employ. & 1.003 & 0.990 & 1.010 & $0.978 *$ & 1.026 & 1.013 \\
\hline Pop. Density & 1.001 & 1.002 & 0.977 & 1.000 & 0.989 & 1.003 \\
\hline $\begin{array}{l}\text { Worker/Owner } \\
\text { Ratio }\end{array}$ & 1.040 & 1.134 & 1.067 & 1.110 & 0.886 & 0.820 \\
\hline \multicolumn{7}{|l|}{ Agric. System } \\
\hline Mixed & REF. & REF. & REF. & REF. & REF. & REF. \\
\hline Horticulture & $0.481 * * *$ & $0.001 * * *$ & $4.219 * * *$ & $2.085^{* *}$ & 0.692 & 0.831 \\
\hline Dairy & 0.852 & $0.436^{*}$ & $2.030^{\wedge}$ & 0.942 & 0.610 & 1.759 \\
\hline Grain & 1.001 & $0.465^{*}$ & 1.460 & 1.092 & 0.664 & 1.731 \\
\hline \multicolumn{7}{|c|}{ Cohort } \\
\hline $1850-1870$ & REF. & REF. & REF. & REF. & REF. & REF. \\
\hline $1871-1890$ & 1.042 & 0.817 & $1.645^{* *}$ & 1.073 & 1.236 & 1.414 \\
\hline 1891-1910 & $1.396^{* *}$ & 1.181 & $2.918 * * *$ & $1.523 * * *$ & $1.464^{\wedge}$ & $1.716^{* *}$ \\
\hline 1911-1922 & $1.895 * *$ & $1.841 * *$ & $1.964^{*}$ & $1.714^{* *}$ & $1.639 \wedge$ & $2.673 * *$ \\
\hline \multicolumn{7}{|c|}{ Interaction Terms } \\
\hline $\begin{array}{l}\text { N Brothers x } \\
\text { Horticulture }\end{array}$ & $1.383 * * *$ & 0.983 & $0.597 * * *$ & 0.954 & $1.269 * *$ & 1.037 \\
\hline $\begin{array}{l}\text { N Brothers } x \\
\text { Dairy }\end{array}$ & 1.089 & 0.941 & $0.767^{*}$ & 0.973 & 0.946 & 1.085 \\
\hline $\begin{array}{l}\text { N Brothers x } \\
\text { Grain }\end{array}$ & 0.938 & 0.993 & 0.812 & 0.967 & $0.911^{*}$ & 1.022 \\
\hline $\begin{array}{l}\text { N Sisters x } \\
\text { Horticulture }\end{array}$ & $1.107^{*}$ & 1.062 & $0.515^{* * *}$ & 0.957 & $0.528^{* * *}$ & $1.343 * * *$ \\
\hline $\begin{array}{l}\mathrm{N} \text { sisters } \mathrm{x} \\
\text { Dairy }\end{array}$ & 1.043 & 1.048 & 0.961 & 1.064 & 1.129 & 0.847 \\
\hline $\begin{array}{l}\text { N Sisters } x \\
\text { Grain }\end{array}$ & 1.058 & 0.995 & 0.968 & 0.959 & $1.207^{*}$ & 0.949 \\
\hline Wald Chi (df) & $2182.56(23)$ & $1563.80(23)$ & $3153.38(23)$ & $2576.72(23)$ & $1431.58(23)$ & 2051.13(23) \\
\hline $\mathrm{N}$ & 2567 & 2567 & 2567 & 2429 & 2429 & 2429 \\
\hline N event & 680 & 205 & 172 & 734 & 279 & 249 \\
\hline
\end{tabular}

$\wedge p<0.10, * p<=0.05, * * p<=0.01, * * * p<=0.001$ 
Table 5 Results of the competing risk models with interaction effects, differentiated for migration destination and sex, farmers' children

\begin{tabular}{|c|c|c|c|c|c|c|}
\hline \multirow{3}{*}{ Variables } & \multirow{3}{*}{$\begin{array}{l}\text { Local } \\
\text { Migration }\end{array}$} & \multicolumn{2}{|c|}{ Sons (Model 5.1) } & \multicolumn{3}{|c|}{ Daughters (Model 5.2) } \\
\hline & & $\begin{array}{l}\text { Rural } \\
\text { Migration }\end{array}$ & $\begin{array}{l}\text { Urban } \\
\text { Migration }\end{array}$ & $\begin{array}{l}\text { Local } \\
\text { Migration }\end{array}$ & $\begin{array}{l}\text { Rural } \\
\text { Migration }\end{array}$ & $\begin{array}{l}\text { Urban } \\
\text { Migration }\end{array}$ \\
\hline & & \multicolumn{5}{|c|}{ Individual Factors } \\
\hline $\mathrm{N}$ brothers & 1.104 & 0.923 & 1.111 & 1.003 & 0.960 & 1.062 \\
\hline N sisters & 0.983 & 1.130 & $0.647 * * *$ & $1.081^{\wedge}$ & 1.059 & 1.110 \\
\hline Firstborn & 1.249 & $0.701^{\wedge}$ & $0.525^{* *}$ & 1.056 & 0.766 & 1.294 \\
\hline Lastborn & $1.290^{\wedge}$ & 0.783 & 0.698 & 0.801 & $0.557 * *$ & 0.871 \\
\hline \multicolumn{7}{|l|}{ Religion } \\
\hline Catholic & REF. & REF. & REF. & REF. & REF. & REF. \\
\hline Liberal Prot. & 1.032 & 0.682 & 1.367 & 1.015 & 0.822 & 1.106 \\
\hline Orthod. Prot. & $1.584^{* *}$ & 0.945 & 0.954 & 0.991 & 1.028 & 0.904 \\
\hline Oth./Non & 0.748 & 0.698 & 1.681 & 0.902 & 0.811 & 1.173 \\
\hline \multicolumn{7}{|c|}{ Regional Factors } \\
\hline Impartibility & $0.829 \wedge$ & 1.371 & 1.030 & 0.982 & 1.217 & 0.989 \\
\hline Alt. Employ. & 0.993 & 0.994 & 1.013 & 1.006 & 1.031 & $0.960^{\wedge}$ \\
\hline Pop. Density & $0.929^{*}$ & $0.652^{\wedge}$ & 1.034 & 0.989 & $0.644^{*}$ & 0.994 \\
\hline $\begin{array}{l}\text { Worker/Owner } \\
\text { Ratio }\end{array}$ & $1.197^{*}$ & $1.253^{*}$ & 0.939 & 0.904 & 0.985 & 1.030 \\
\hline \multicolumn{7}{|l|}{ Agric. System } \\
\hline Mixed & REF. & REF. & REF. & REF. & REF. & REF. \\
\hline Horticulture & 1.214 & $2.892^{* *}$ & $0.251^{*}$ & $0.509^{*}$ & $0.355^{*}$ & $7.715^{* * *}$ \\
\hline Dairy & 0.974 & 1.768 & 1.436 & 1.322 & 0.617 & 1.206 \\
\hline Grain & 0.952 & 1.356 & 1.632 & 0.903 & 1.410 & 1.612 \\
\hline \multicolumn{7}{|c|}{ Cohort } \\
\hline 1850-1870 & REF. & REF. & REF. & REF. & REF. & REF. \\
\hline 1871-1890 & 0.945 & 1.383 & 1.746 & 1.176 & $1.551^{\wedge}$ & $2.142^{*}$ \\
\hline 1891-1910 & $1.737^{* *}$ & $1.576^{\wedge}$ & $2.930 * *$ & $1.616^{* *}$ & $1.845^{* *}$ & $3.360 * * *$ \\
\hline 1911-1922 & 1.502 & $3.480 * * *$ & 1.971 & $1.791^{* *}$ & $2.526 * * *$ & $5.445 * * *$ \\
\hline \multicolumn{7}{|c|}{ Interaction Terms } \\
\hline $\begin{array}{l}\text { N Brothers x } \\
\text { Horticulture }\end{array}$ & 0.998 & 1.120 & 0.886 & 1.117 & $1.494^{*}$ & $0.594 * * *$ \\
\hline $\begin{array}{l}\text { N Brothers X } \\
\text { Dairy }\end{array}$ & 0.963 & 1.081 & $0.768^{\wedge}$ & 0.933 & 1.088 & $1.302^{*}$ \\
\hline $\begin{array}{l}\text { N Brothers x } \\
\text { Grain }\end{array}$ & 0.952 & 1.018 & 0.918 & 1.015 & 1.039 & 0.938 \\
\hline $\begin{array}{l}\text { N Sisters x } \\
\text { Horticulture }\end{array}$ & $0.868^{*}$ & $0.479 * * *$ & $1.930 * * *$ & 0.938 & 0.970 & 0.996 \\
\hline $\begin{array}{l}N \text { sisters } \mathrm{X} \\
\text { Dairy }\end{array}$ & 1.101 & 0.692 & $1.676 * * *$ & 0.875 & 1.080 & $0.602 * * *$ \\
\hline $\begin{array}{l}\text { N Sisters x } \\
\text { Grain }\end{array}$ & 0.985 & 0.747 & 1.201 & 0.938 & 0.947 & 0.847 \\
\hline Wald Chi (df) & $1772.52(23)$ & $5964.82(23)$ & $243.82(23)$ & $350.69(23)$ & $362.46(23)$ & $3366.92(23)$ \\
\hline $\mathrm{N}$ & 1509 & 1509 & 1509 & 1479 & 1479 & 1479 \\
\hline $\mathrm{N}$ event & 298 & 136 & 75 & 366 & 166 & 102 \\
\hline
\end{tabular}

$\wedge \mathrm{p}<0.10,{ }^{*} \mathrm{p}<=0.05,{ }^{*} \mathrm{p}<=0.01,{ }^{* * *} \mathrm{p}<=0.001$ 
Remarkably, we see only limited effects of the family composition on migration destinations. Farmers' sons in all commercialised areas, such as dairy farming $(H R=1.676)$ and horticulture $(H R=1.930)$ were more likely to go to a city (and abandon farming) when they had more sisters, while sisters in horticulture regions kept farmers' sons from migrating locally $(H R=0.868)$ or regionally $(H R=0.479)$. In mixed agricultural systems sisters kept sons away from migrating to a city (0.647), while also being the first born had a negative effect on performing an urban move $(H R=0.525)$. Does this mean, after all, that family capital generated by brothers did allow men to continue farming, and that this was not the case in farms with more girls? For daughters the effects are partly different and even more complicated: Daughters in horticulture regions without siblings had a very high chance to move to a city $(H R=7.715)$, instead of migrating elsewhere. However, many sisters in dairy farming $(H R=0.602)$ or horticulture regions $(H R=0.594)$ kept daughters away from moving to a city, while daughters were more likely to perform urban moves when they had several brothers $(H R=1.302)$. Finally, the results show that lastborn daughters were less likely to perform intra-rural moves over longer distances $(>10 \mathrm{~km})$, which could relate to them more often being kept at home to support their parents. In general, it is difficult to explain these outcomes, but in any case, adding these interactions has shown that to understand the impact of the sibling set on migration decisions of farmers' children, the actual division of labour, as it differs from one agricultural type to another, needs to be taken into account.

\section{CONCLUSION}

From the late nineteenth century onwards, economic opportunities in many rural areas of the Netherlands started to decline. There were simply fewer niches available for each new generation. In this article we have studied the consequences from both an individual, familial and regional perspective. Our main purpose was to explore whether a competing risk multi-level analysis could be helpful in unravelling the different factors effecting decisions to leave the parental home and, if so, in what direction. The study revealed that the strength and direction of effects differed by type of agriculture. However, we did not go into the history of each rural region in depth, which would have been beyond the scope of this article. In future research, we hope to expand and refine our models with, for instance, information on migration experiences of RPs' parents and their siblings as indicators of possible 'spatial capital' which reduces the information costs for individual children. Also, we aim to add more contextual information (such as transport facilities) which might affect likelihood and directions of moving. Finally, it will be of interest to see whether our 'final moves' really reflect staying or leaving agriculture, as the RPs might have moved again, e.g. from a village to a city. Also, their occupations after leaving home may actually be more revealing than their migration destinations.

We have shown how, for individual children of farmers and rural workers, the questions of whether, when and where they had to eventually move from home depended on their gender, age, number and sex of siblings, and their position in the sibling order. We have demonstrated how rank order mattered for the leaving home of workers' sons as well as for farmers' sons and daughters, and also how its impact decreased with age. We have also studied economic and agricultural characteristics of the region to understand timing and type of leaving home. The most important factor turned out to be the type of agriculture, and we found quite strong interaction effects of sibship and agricultural type. This confirms the impression from the literature that in e.g. dairy farming or grain cultivation very different gender-specific inputs of children were required. We can now relate these specific forms of family farming - sometimes needing more boys, sometimes needing more girls - to the likelihood of leaving home and even to the likelihood of leaving agriculture (which we infer from moving to a city). The exercise has shown that a competing-risk analysis of youth migration helped to decompose the leaving home process of children into different streams of groups of rural youths. This decomposition helped to better understand the ongoing migration processes in nineteenth century Netherlands and can be useful for studying migration processes in today's developing countries. In such countries as well, individual migration destinies result from the complex interplay of family setting and local conditions in a rural environment (e.g. Harbison 1981). Our paper provides an example on how to link these processes to different migration destinations using a competing-risk perspective. 


\section{ACKNOWLEDGEMENTS}

We would like to thank the three anonymous reviewers for thorough comments and valuable suggestions. Additionally, we would like to thank Jornt Mandemakers for his comments and ideas, which helped to improve this paper.

This paper has been presented at the Seventh Day of Historical Demography, on the $4^{\text {th }}$ of December 2014 in Wageningen (The Netherlands).

\section{REFERENCES}

Abramitzky, R., Boustan, L.P. \& Eriksson, K. (2013). Have the poor always been less likely to migrate? Evidence from inheritance practices during the Age of Mass Migration. Journal of Development Economics, 102, 2-14.

Adams, J.W. \& Kasakoff, A.B. (1992). The farm family economy in the American North, 1775-1875: an exploration of sibling differences. Continuity and Change, 7(03), 357-375. DOI: http://dx.doi.org/10.1017/S0268416000001715

Arnoldus, D. (2003). Van stapelmarkt naar poort van Europa. Ontwikkeling en diversiteit van een open economie. In: T. de Nijs \& E. Beukers (Eds.), Geschiedenis van Holland. Dee/ III a 17952000 (pp.187-259). Hilversum: Verloren.

Augustins, G. (2002). The perpetuation of families and the molding of personal destinies. In: D.I. Kertzer \& M. Barbagli (Eds), Family life in the long nineteenth century, 1789-1912 (pp. 322348). New Haven: Yale University Press.

Baert, J. (1949). Deling van grond bij boerennalatenschap. De Pacht. Maandblad van de Nederland sche pachtraad, 9, 134-152.

Barrera-González, A. (1992). Eldest and younger siblings in a stem-family system: the case of rural Catalonia. Continuity and Change, 7, 335-355.

DOI: http://dx.doi.org/10.1017/S0268416000001703

Béaur, G. (2004). Land transmission and inheritance practices in France during the ancien régime: differences of degree or kind? In: D. Green \& A. Owens (Eds.), Family welfare: gender, proper ty, and inheritance since the seventeenth century (pp. 31-46). Westport/London: Praeger.

Beekink, E., Boonstra, O., Engelen, T. \& Knippenberg, H. (2003). Nederland in verandering: maatschappelijke ontwikkelingen in kaart gebracht. Amsterdam: Aksant.

Berg, H. (1989). Vrouwen op het Hoge Land in Groningen, 1880-1914. In: F. Backerra, L. Flapper, A. Hobbelink, M. van der Steen, C. Verstoep \& C. Visser (Eds.), Vrouwen van het land. Anderh alve eeuw plattelandsvrouwen in Nederland (pp. 28-44). Zutphen: De Walburg Pers.

Berkner L.K. \& Mendels F.F. (1978). Inheritance systems, family structure, and demographic patterns in Western Europe, 1700-1900. In: C. Tilly \& L.K. Berkner (Eds.), Historical studies of changing fertility (pp. 209-223). Princeton: Princeton University Press.

Beyersmann, J., Latouche, A., Buchholz, A. \& Schumacher, M. (2009). Simulating competing risk data in survival analysis. Statistics in Medicine, 28(6), 956-971.

DOI: $10.1002 / \operatorname{sim} .3516$

Bieleman, J. (2008). Boeren in Nederland. Geschiedenis van de landbouw 1500-2000. Amsterdam: Boom.

Blaauboer, M. (2011). The impact of childhood experiences and family members outside the house hold on residential environment choices. Urban Studies, 48(8), 1635-1650.

DOI: $10.1177 / 0042098010377473$

Bonneuil, N., Bringé, A. \& Rosental, P.-A. (2007). Familial components of first migrations after mar riage in nineteenth- century France. Social History, 33(1), 36-59.

DOI: $10.1080 / 03071020701833325$

Bras, H. \& Neven, M. (2007). The effects of siblings on the migration of women in two rural areas of Belgium and the Netherlands, 1829-1940. Population Studies, 61(1), 53-71. DOI:10.1080/00324720601048319

Bras, H. \& Kok, J. (2004). Naturally, every child was supposed to work. Determinants of the leaving home process in the Netherlands, 1850-1940. In: F. van Poppel, M. Oris \& J. Lee (Eds.), The road to independence. Leaving home in western and eastern societies, 16th and 20th centuries (pp. 403-450). Bern: Peter Lang. 
Brettell, C.B. (1987). Men who migrate, women who wait: Population and history in a Portuguese parish. Princeton: Princeton University Press.

Cameron, A.C., Gelbach, J.B. \& Miller, D.L. (2011). Robust inference with multiway clustering. Journal of Business \& Economic Statistics, 29(2), 238-249. DOI:10.1198/jbes.2010.07136

Cleves, M., Gutierrez, R.G., Gould, W. \& Marchenko, Y.V. (2010). An introduction to survival analysis in using Stata. Stata Press.

Cox, D.R. (1972). Regression models and life-tables. Journal of the Royal Statistical Society, Series B (Methodological), 34(2), 187-220.

De Bie, R. (2009). De economisch-geografische indelingen van het CBS, 1917-1960. Den Haag/ Heerlen: Centraal Bureau voor de Statistiek.

Dribe, M. (2004). Leaving home as a family strategy in times of economic and demographic stress. The case of rural Scania, Sweden 1829-1866. In: F. van Poppel, M. Oris \& J. Lee (Eds.), The road to independence. Leaving home in western and eastern societies, 16th and 20th centuries (pp. 85-116). Bern: Peter Lang.

Dribe, M. (2000). Leaving home in a peasant society. Economic fluctuations, household dynamics and youth migration in southern Sweden, 1829-1866. Södertalje: Almqvist \& Wiksell International.

Fine, J.P. \& Gray, R.J. (1999). A proportional hazards model for the subdistribution of a competing risk. Journal of the American Statistical Association, 94(446), 496-509. DOI:10.1080/01621459.1999.10474144

Florey, F.A. \& Guest, A.M. (1988). Coming of age among U.S. farm boys in the late 1800s: occupa tional and residential choices. Journal of Family History, 13(2), 233-249.

DOI: 10.1177/036319908801300205

Egerbladh, I., Kasakoff, A. B. \& Adams, J.W. (2007). Gender differences in the dispersal of children in northern Sweden and the northern USA in 1850. History of the Family, 12(1), 2-18 DOI:10.1016/j.hisfam.2007.05.001

Gielen, A. (1989). De 'natuurlijke bestemming' van een boerendochter. De opvoeding van boeren meisjes in Horst in het begin van de twintigste eeuw. In: F. Backerra, L. Flapper, A. Hobbelink, M. van der Steen, C. Verstoep \& C. Visser (Eds.), Vrouwen van het land. Anderhalve eeuw plattelandsvrouwen in Nederland (pp. 101-111). Zutphen: De Walburg Pers.

Gooley, T.A., Leisdenring, W., Crowley, J. \& Storer, B.E. (1999). Estimation of failure probabilities in the presence of competing risks: New representations of old estimators. Statistics in Medicine, $18,695-706$.

Gordon, G. (1989). The Bevolkingsregisters and their use in analyzing co-residential behaviour of the elderly. Den Haag: NIDI rapport, 9.

Grambauer, N., Schumacher, M. \& Beyersmann, J. (2010). Proportional subdistribution hazards mod eling offers a summary analysis, even if misspecified. Statistics in Medicine, 29(7-8), 875-884. DOI: 10.1002/sim.3786

Harbison, S.F. (1981). Family structure and family strategy in migration decision making. In: G.F. De Jong \& R.W. Gardner (Eds.), Migration decision making: multidisciplinary approaches to mi crolevel studies in developed and developing countries (pp. 225-251). New York: Pergamon.

Hendrickx, F.M.M. (1993). From weavers to workers. Demographic implications of an economic transformation in Twente (the Netherlands) in the nineteenth century. Continuity and Change, 8, 321-355.

DOI: http://dx.doi.org/10.1017/S0268416000002101

Hendrickx, F.M.M. (2003). Family, farm, and factory: Labor and the family in the transition from protoindustry to factory industry in 19th-century Twente, the Netherlands. The History of the Family, 8(1), 45-69.

DOI:10.1016/S1081-602X(03)00006-X

Heuvel, H.W. (1927). Oud Achterhoeksch boerenleven, het gehele jaar rond. Deventer: Kluwer. Hofstee, E.W. (1950). De landbouw en de migratie. Economisch-statistische berichten, 1024-1026.

Jensen, R. \& Miller, N.R. (2011). Keepin' 'em down on the farm: old age security and strategic underinvestment in children. Unpublished manuscript, Department of Economics, Brown University.

Kesztenbaum L. (2008). Places of life events as bequestable wealth. Family territory and migration in France, 19th and 20th century. In: T. Bengtsson \& G. Mineau (Eds.), Kinship and demographic behavior in the past (pp. 155-184). Dordrecht: Springer. 
Klep, P. (2010). Kleine boeren en grote gezinnen in crisistijd (1920-1970) - een nieuwe these. In: J. Kok \& J. van Bavel (Eds.), De levenskracht der bevolking. Sociale en demografische kwesties in de Lage Landen tijdens het interbellum (pp. 141-196). Leuven: Universitaire Pers Leuven.

Klep, P. (2011). Gezinssolidariteit en rotten kids: Schaarste, seks en het vierde gebod op het platteland in Nederland in de twintigste eeuw. Nijmegen: Radboud Universiteit Nijmegen.

Knippenberg, H. \& de Pater, B. (1988). De eenwording van Nederland. Schaalvergroting en integratie sinds 1800. Nijmegen: SUN.

Knippenberg, H. (1992). De religieuze kaart van Nederland. Omvang en geografische spreiding van de godsdienstige gezindten vanaf de Reformatie tot heden. Assen/Maastricht: Van Gorcum.

Kok, J. (1997). Youth labor migration and its family setting, The Netherlands 1850-1940. The History of the Family, 2(4), 507-526.

DOI:10.1016/S1081-602X(97)90027-0

Kok, J. (2003). Nederland in beweging. Aspecten van migratie, 1876-1960. In: E. Beekink, O. Boonstra, T. Engelen \& H. Knippenberg (Eds.), Nederland in verandering. Maatschappelijke ontwikkelingen in kaart gebracht (pp. 25-44). Amsterdam: Aksant.

Kok, J. (2006). Sources for the historical demography of The Netherlands in the $19^{\text {th }}$ and early $20^{\text {th }}$ centuries. In : Y.-C. Chuang, T. Engelen \& A.P. Wolf (Eds.), Positive or preventive. Fertility developments in Taiwan and the Netherlands, 1850-1950 (pp. 41-51). Amsterdam: Aksant.

Kok, J. \& van Bavel, J. (2006). Stemming the tide. Denomination and religiousness in the Dutch fertility transition, 1845-1945. In: R. Derosas \& F. Van Poppel (Eds.), Religion and the decline of fertility in the Western World (pp. 83-105). Dordrecht: Springer.

Kok, J. \& Bras, J. (2008). Clustering and dispersal of siblings in the North-Holland countryside, 18501940. Historical Social Research/Historische Sozialforschung, 33(3), 278-300.

Kok, J., Mandemakers, K. \& Damsma, D. (2010). Atrophied hearts? Partner choice and social repro duction of farmers in the north-western part of the Netherlands in the 19th and early 20th cen tury. In: M. P. Arrizabalaga, I. Bolovan, M. Eppel, J. Kok, M. L. Nagata (Eds.), Many paths to happiness? Studies in population and family history. A festschrift for Antoinette FauveChamoux (pp. 362-387). Amsterdam: Aksant.

Kok, J., Mandemakers, K. \& Mönkediek, B. (2014). Flight from the land? Migration flows of the rural population of the Netherlands, 1850-1940. Espace Populations Sociétés, 2014-1.

Kooij, P. (1985). Stad en platteland. In: F.L. van Holthoon (Ed.), De Nederlandse samenleving sinds 1815. Wording en samenhang (pp. 93-115). Assen: Van Gorcum.

Lodder, T. (1989). Boterbereiding en boerinnenverzet in Friesland 1880-1910. In: F. Backerra, L. Flap per, A. Hobbelink, M. van der Steen, C. Verstoep \& C. Visser (Eds.), Vrouwen van het land. Anderhalve eeuw plattelandsvrouwen in Nederland (pp. 45-65). Zutphen: De Walburg Pers.

Long, J. (2005). Rural-urban migration and socioeconomic mobility in Victorian Britain. The Journal of Economic History, 65(1), 1-35.

DOI: http://dx.doi.org/10.1017.S0022050705050011

Mandemakers K. (2000). Netherlands - The Historical Sample of the Netherlands. In: P. Kelly Hall, R. McCaa \& G. Thorvaldsen (Eds.), Handbook of International Historical Microdata (pp. 149178). Minnesota: Minnesota Population Center.

Mandemakers, K. (2006). Building life course datasets from population registers by the Historical Sample of the Netherlands (HSN). History and Computing, 14(1-2), 87-108.

Mastboom, J.M. (1996). Protoindustrialization and agriculture in the eastern Netherlands: Industrialization and the theory of protoindustrialization. Social Science History, 20(2), 235-258. DOI: $10.2307 / 1171238$

McQuillan, K. (1998). Family composition, birth order and marriage patterns: Evidence from rural Alsace, 1750-1885. Annales de démographie historique, 2008(1), 57-71.

Minderhoud, G. (1917). Het landbouwbedrijf op de Groningse Klei. Deventer.

Paping, R. (2004). Family strategies concerning migration and occupations of children in a market-oriented agricultural economy. The History of the Family, 9(2), 159-191.

DOI:10.1016/j.hisfam.2004.01.003

Saal, C.D. (1958). Het boerengezin in Nederland. Sociologische grondslagen. Deel I. Bedrijfssociolo gische aspecten. Assen: Van Gorcum.

Sarti, R. (2007). Criados, servi, domestiques, gesinde, servants: for a comparative history of domestic service in Europe. Obradoiro de Historia Moderna, 16, 9-39.

URI: http://hdl.handle.net/10347/3909 
Shortall, S. (2000). In and out of the milking parlour: a cross-national comparison of gender, the dairy industry and the state. Women's Studies International Forum, 23(2), 247-257.

DOI: 10.1016/S0277-5395(00)00075-3

Stouffer, S.A. (1940). Intervening opportunities: A theory relating mobility and distance. American Sociological Review, 5(6), 845-867.

Swierenga, R.P. \& Saueressig-Schreuder, Y. (1983). Catholic and protestant emigration from the Netherlands in the 19th century: A comparative social structural analysis. Tijdschrift voor Economische en Sociale Geografie, 74(1), 25-40.

DOI: 10.1111/j.1467-9663.1983.tb01493.x

Verslag van den landbouw in Nederland (1875). Grootte der gronden tijdens de invoering van het kadaster. 's-Gravenhage: Van Weelden en Mingelen.

Van Blom, D. (1915). Boerenerfrecht (met name in Gelderland en Utrecht). De Economist, 64, 847896.

Van der Meer, A. \& Boonstra, O. (2006). Repertorium van Nederlandse gemeenten, 1812-2006. Den Haag: DANS.

Van Poppel, F. (1992). Trouwen in Nederland. Een historisch-demografische studie van de $199^{\circ}$ en vroeg-20 eeuw. Wageningen: Landbouwuniversiteit.

Verstoep, C. (1989). Een vrouwenambacht van moeder op dochter doorgegeven. Boerenkaasbereiding in Midden-Nederland, circa 1895-1940. In: F. Backerra, L. Flapper, A. Hobbelink, M. van der Steen, C. Verstoep \& C. Visser (Eds.), Vrouwen van het land. Anderhalve eeuw plattelandsvrouwen in Nederland (pp. 66-78). Zutphen: De Walburg Pers.

Wegge, S.A. (1999). To part or not to part: Emigration and inheritance institutions in nineteenthcentury Hesse-Kassel. Explorations in Economic History, 36(1), 30-55. DOI:10.1006/exeh.1998.0703

Wintle, M. (1992). Push factors in emigration: the case of the province of Zeeland in the nineteenth century. Population Studies, 46(3), 523-537. DOI:10.1080/0032472031000146496

Wooldridge, J.M. (2003). Cluster-sample methods in applied econometrics. The American Economic Review, 93(2), 133-138. 